\title{
An overview of big data analytics application in supply chain management published in 2010-2019
}

\author{
Iman Ghalehkhondabia* (D), Ehsan Ahmadia (D), Reza Maihamia \\ a Our Lady of the Lake University, School of Business and Leadership, San Antonio, TX, United States of America \\ *ighalehkhonda@ollusa.edu
}

\begin{abstract}
Paper aims: This study reviews the available literature regarding big data analytics applications in supply chain management and provides insight on topics that received a good deal of attention and topics that still require investigation. This review considers the expansion of big data analytics in supply chain management from 2010 to 2019.

Originality: Beyond displaying the increasing frequency of using big data analytics in supply chain management, the authors also aim to develop a useful categorization of applying business analytics in supply chain management and define opportunities for future research in the field.

Research method: This paper briefly discusses big data applications in supply chain management. Four common steps in review papers are performed: collecting articles (Thomson Reuters Web of Science), descriptive analysis, defining categories, and evaluating the material.

Main findings: According to both information technology development trends and the availability of data, more companies are using big data analytics in their supply chains. About 60\% of the research on big data applications in supply chain management were published after 2017. These publications have increasingly focused on big data applications in predictive analysis, rather than in the other three types of data analysis: descriptive analysis, diagnostic analysis, and prescriptive analysis.

Implications for theory and practice: This review shows that the collected data by many companies can be analyzed using big data analytics methods to develop the business growth plan, market direction forecast, manufacturing process simulation, delivery optimization, inventory management, and marketing and sales processes, among many other activities in a supply chain. The number of articles using case studies in the literature is greater than the number of theoretical publications. This shows that big data analytics has now been properly developed for practical applications, rather than just being a theoretical concept.
\end{abstract}

\section{Keywords}

Big data analytics. Business processes. Manufacturing systems. Logistics systems. Supply chain management.

How to cite this article: Ghalehkhondabi, 1., Ahmadi, E., \& Maihami, R. (2020). An overview of big data analytics application in supply chain management published in 2010-2019. Production, 30, e20190140. https://doi.org/10.1590/0103-6513.20190140.

Received: Nov. 13, 2019; Accepted: Apr. 21, 2020.

\section{Introduction}

\subsection{Big data}

"I have just bought a house! 1 have bought a big house!" When people talk about big objects, generally there is a common sense of the word "BIG". When people use the word "big house", they are usually talking about the house area or the number of bedrooms. But, what does it mean when we use the word "big data", and what differentiates "big data" from the usual usage of the term "data"?

Big data is a developing phenomenon in the field of Information Technology (Vera-Baquero et al., 2015). Big data includes data sets that can't be analyzed by the common traditional data analysis tools (Costello \& Prohaska, 2013). Big data refers to a high volume of data with a high velocity and a high variety; these 
properties require more efficient methods than the current ones used in conventional database systems for decision making (Laney, 2001a). Big data enables systems to manage their processes using a large volume of real-world data (Van der Aalst, 2012).

Big data entered the field of practical research in the $21^{\text {st }}$ century; there was no noteworthy research applying big data analytics in other fields before 2000. The main characteristic of big data is simply its huge volume of data, but some other characteristics have been added to this definition over the years. The first time that Big Data was defined by the 3V model (Volume, Velocity, and Variety) was in a study by Laney (2001b). Volume refers to the amount of available data; Velocity refers to the timeliness of the data; and Variety refers to the diversity of the data types, including unstructured, semi-structured, and structured data sets.

Two other important Vs have been added to the definition of big data in the most recent decade. The economic Value refers to the profit gained by analyzing a huge volume of data (ldc-Vesset et al., 2012), and Veracity refers to the considerable amount of uncertainty and imprecision in the big data (Schroeck et al., 2012). (Wamba et al., 2015) integrated all of the Vs in one place and introduced the $5 \mathrm{~V}$ big data framework for the first time. Figure 1 represents the evolutionary timeline of the big data concept, as well as the most-cited articles using big data in manufacturing, logistics, and supply chain management.

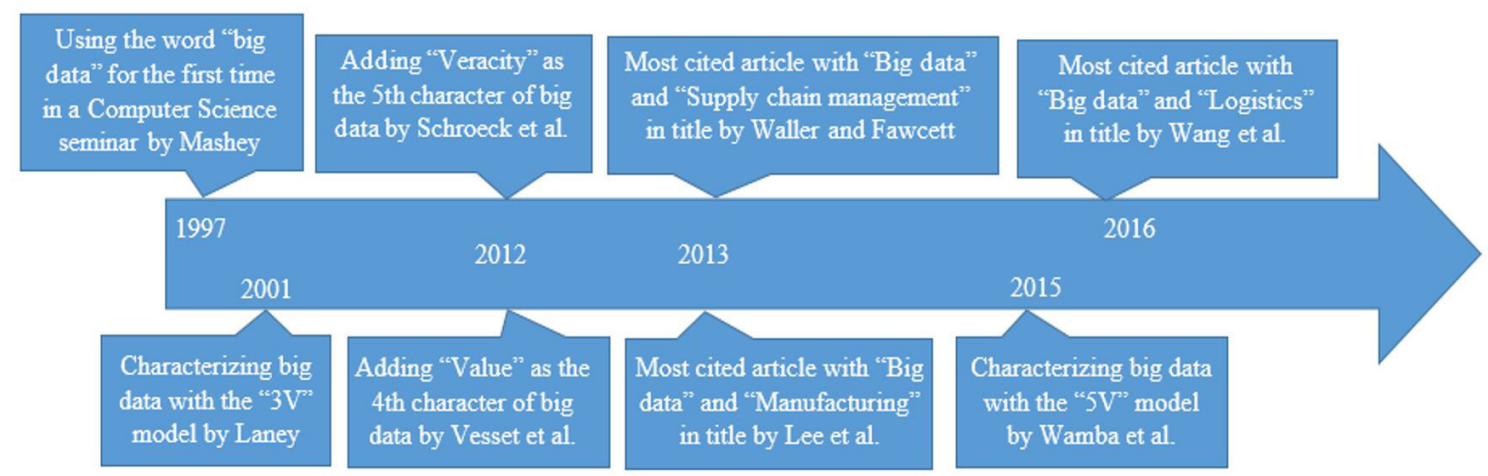

Figure 1. Big data framework evolution during the time (ldc-Vesset et al., 2012; Laney, 2001b; Lee et al., 2013; Mashey, 1997; Schroeck et al., 2012; Waller \& Fawcett, 2013; Wamba et al., 2015; Wang et al., 2016).

Big data analysis is a process that transforms terabytes of low-value data into a small amount of high-value data, which shows an overview of the company using just a small slice of the overall picture (Fisher et al., 2012). A big data system can be separated into four consecutive phases: data generation, data acquisition, data storage, and data analytics (Hu et al., 2014).

\subsection{Big data applications in a business environment}

Because of recent technology developments, obtaining data is not a difficult task anymore, though the efficient use of data to achieve strategic and operational goals is still an area of concern (Gobble, 2013). Traditionally, businesses used their own data to make decisions, but the development of new technologies gives businesses access to various brand-new types of datasets (Jha et al., 2016). The usage of social networking is booming at a quick pace, and a huge volume of consumer data is being provided to businesses. Big data has become a major keyword in the technology world and has shown its useful applications in other areas as well. For example, big data has been successfully used for fraud prevention and detection in financial transactions (Jha et al., 2016).

Data plays a vital role in developing today's operational systems. Big data can be used to increase business competitiveness, according to the recent development of data. Today's business environment provides a huge opportunity, since a large volume of data is generated every minute. Most companies use big data for continual improvement. Four steps are commonly used in data analytics: The first step is to ensure that the available data is clean, structured and organized, which can then be used for further analysis. The second step is to ensure that the right data is accessible in the right form, the right time, and the right place. The third step is to do quantitative analyses, such as descriptive analytics. The fourth step is to apply advanced analytics such as predictive analytics, automated algorithms, and real-time data analysis. Using big data in the last step requires particular expertise in advanced data analytics (Sanders, 2016). 
Various techniques such as statistics, data mining, machine learning, neural networks, pattern recognition, visualization, etc. are used to extract any valuable information out of big data (Mikavicaa et al., 2015). For example, cloud computing is one of the practices used to store, develop, and deploy big data in business processes.

Decreasing data management costs can increase the desirability of companies to use big data (Schwab et al., 2011). For example, in 2019, storing a terabyte of data using relational traditional databases could cost over $\$ 20000$ for a company (Sonra, 2015), but storing the same amount of data could cost just $\$ 1000-\$ 2000$ using cheap big data technology such as a Hadoop cluster (StatSlice, 2013). Hadoop gained popularity in the area of technology development because of its price and capacity for data storage.

\subsection{Methodology and research questions}

There have been many developments in big data collection and analysis methods in recent years. The author of this paper used the Thomson Reuters Web of Science search tool (Clarivate, 2020) to track the number of "big data" publications over the last decade. Since several studies were performed on the topic of big data, we narrowed our search to the articles that have "big data" in their title. We also tried different combinations of title and topic searches in the Web of Science and came up with the solution that the best combination was to keep "big data" in the title search and the other keywords in the topic. For example, a search for articles with both "big data" and "supply chain" as a topic for the year 2019 gave us 173 articles; several of them were not related to the focus of our study at all. On the other hand, a search for articles with both "big data" and "supply chain" in the title for the year 2019 gave us only 15 articles, with many valuable articles not included. However, a search for articles with "big data" in the title and "supply chain" as a topic for the same year resulted in 54 articles that covered topics related to our study. Our methodology here was the same as that in many other review papers (Mishra et al., 2018; Nguyen et al., 2018) to collect the literature, provide the descriptive analysis (in this section), develop categories of interest, and evaluate the papers (sections 2, 3, and 4).

Figure 2 illustrates the number of published articles from 2010 to 2019 with the word "big data" in their title and "manufacturing", "supply chain", and "business" in the topic. As can be seen in Figure 2, there is an increase in the number of publications in the field in recent years. It is worth nothing that not much research was published on big data before 2010. About 15\% of the big data publications have the word "business" in their topic, and many of publications were dedicated to other fields of study, such as engineering and science. Among the business-related studies, about $46 \%$ of publications focused on "supply chain" and "logistics" in their topic, and about 12\% have manufacturing as their topic.

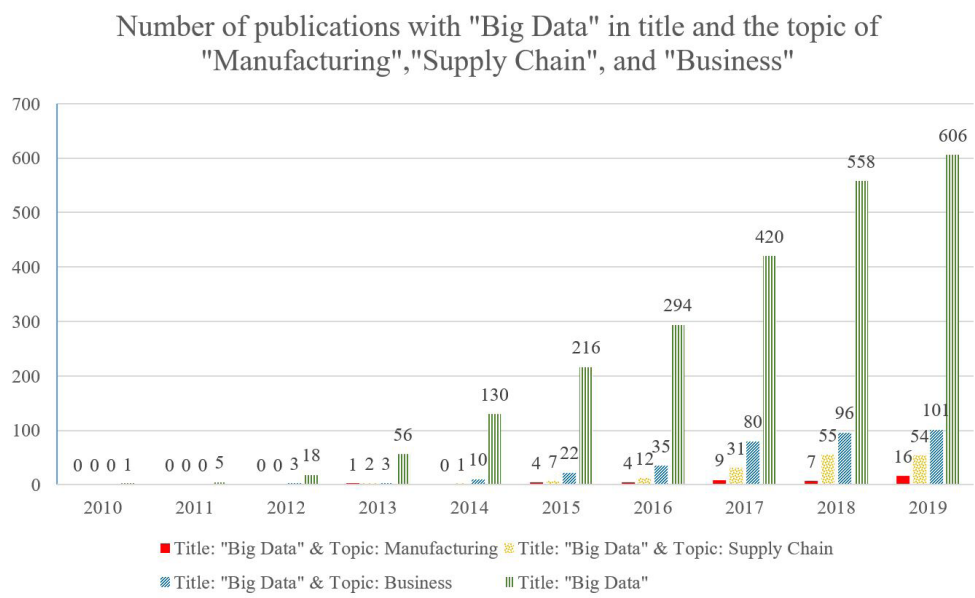

Figure 2. Number of publications with "Big Data” in title (Thomson Reuters Web of Science).

Different academic journals cover different subject areas; therefore, journals that publish most of the papers in an area of research can be a useful guide for those who are looking for the available literature or submitting their own contribution. The Thomson Reuters Web of Science was also used to develop a bibliometric of big data publications containing the terms "supply chain", "logistics", and "manufacturing" when looking at the journal title and impact factor, as can be seen in Figure 3. 
Number of articles with "Big Data" in title and "Manufacturing" in topic

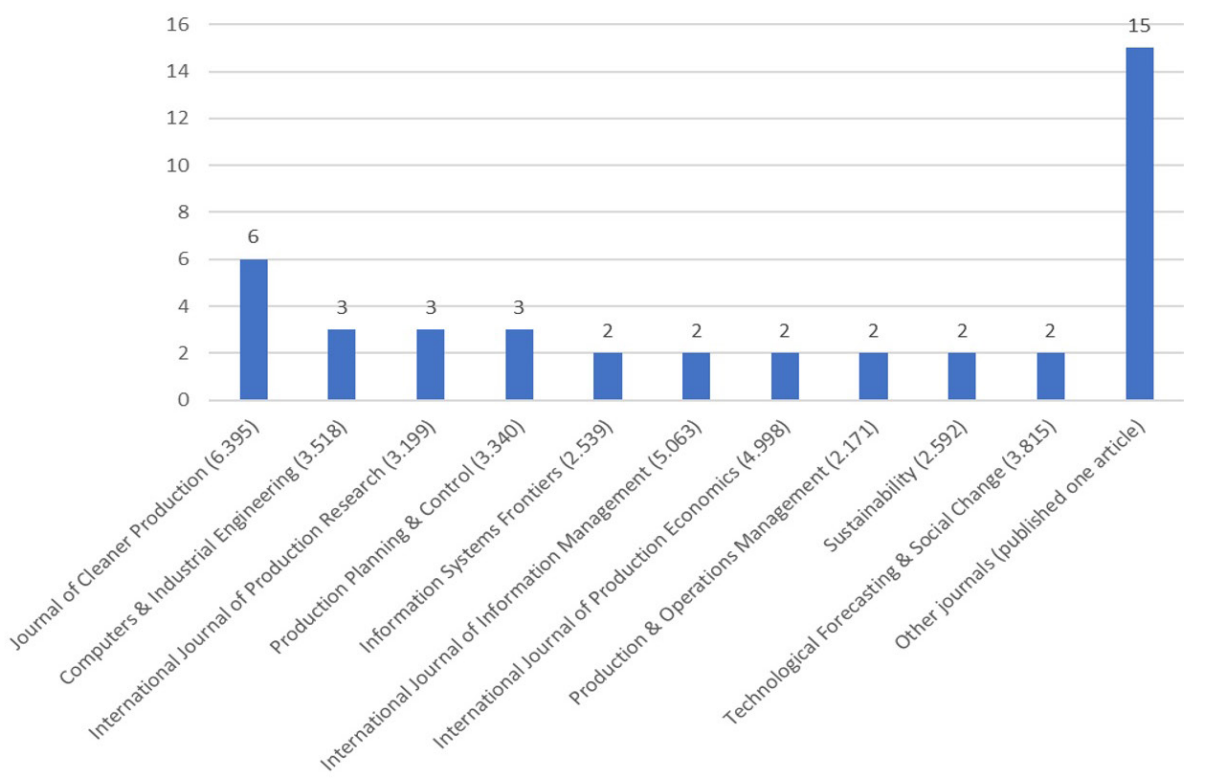
Number of articles with "Big Data" in title and "Supply Chain" and "Logistics" in topic
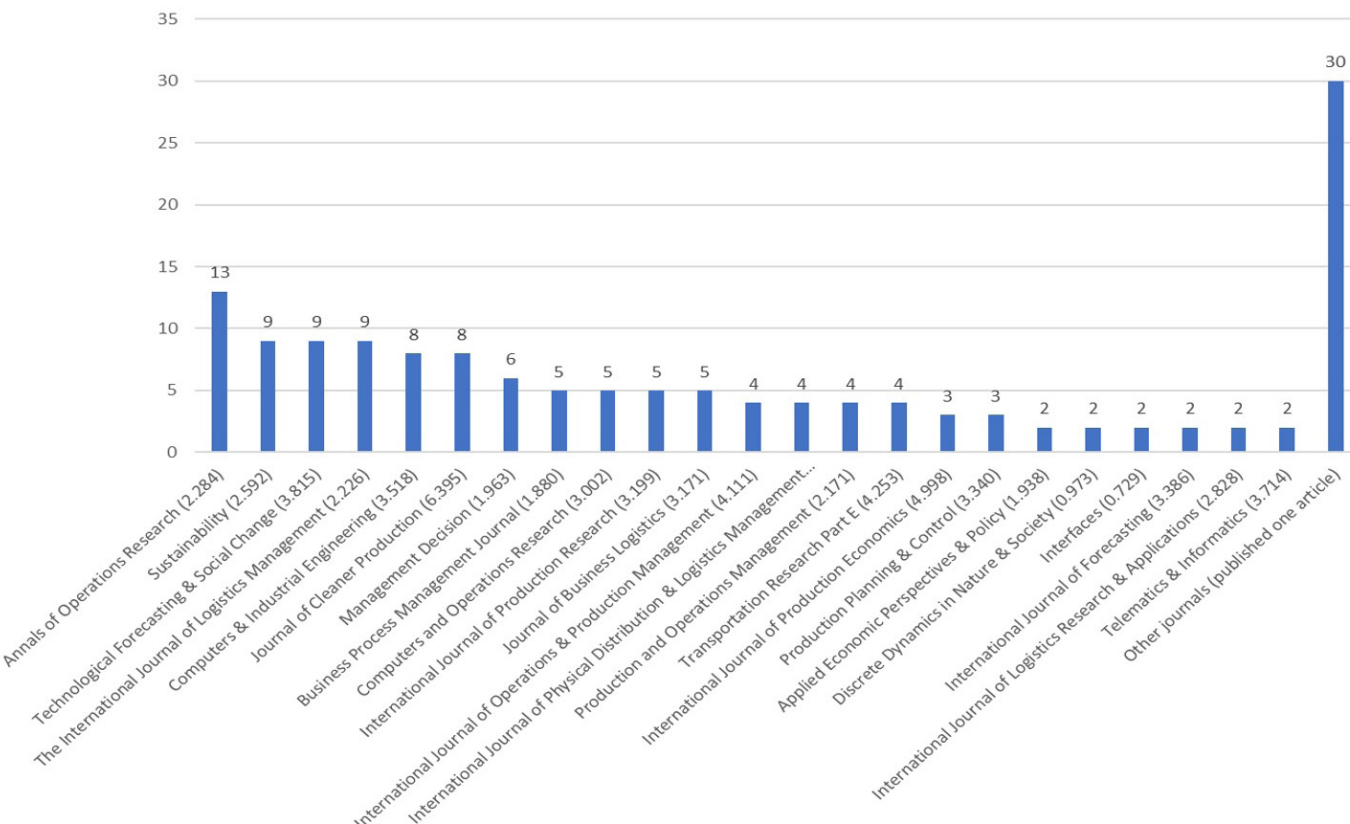

Figure 3. Publishing journal (impact factor in parentheses) with a topic of a) Manufacturing or b) Supply Chain and logistics.

Figure 3 shows that "Annals of Operations Research", "Sustainability", "Technological Forecasting and Social Change" and "The International Journal of Logistics Management" are the journals which published the most papers that applied big data analytics in supply chain management. The greatest impact factor among these journals is for the "Journal of Cleaner Production," with an impact factor of 6.395.

Information technology developments encouraged many researchers and practitioners to use big data analytics in manufacturing systems, logistics processes, and other functions of a supply chain (Akter \& Wamba, 2019; Dubey et al., 2018a; Feng \& Shanthikumar, 2018). Moreover, since the benefits of big data analytics 
have attracted more researchers into the field, several more papers have been written that review the literature and define possible future directions (Barbosa et al., 2018; Dubey et al., 2019; Gupta et al., 2019a; Lamba \& Singh, 2017; Rialti et al., 2019). According to Figure 2, most research in this area has been performed in recent years; therefore, a current literature review can give more insight for researchers who want to focus their work on big data applications in supply chain management. Moreover, our study categorizes the literature into three key areas: manufacturing systems, logistics processes, and supply chain functions. In each category, papers are grouped based on their main topic, and quality papers are summarized in tables to give more information about each paper. The current study is trying to answer the following questions:

- What are the different categories of big data analytics that are used in supply chain management?

- What are the factors that affect the attractiveness of using big data analytics in supply chain management studies?

- What supply chain management research topics are studied more often by big data analytics?

- What are the hurdles and advantages of using big data analytics in supply chain management research? What must be done in the future?

The remainder of this article is dedicated to reviewing published research in the specialized fields. Section 2 surveys published research that looks at applying big data analytics to manufacturing systems. Sections 3 and 4 review the published research with a focus on using big data analytics in supply chain management and logistics processes. In each subsection the subjects most often studied are introduced, and some of the quality papers are summarized in relevant tables. Section 5 concludes this study by discussing the hurdles and advantages of using big data analytics. Moreover, some directions for the future studies are hypothesized in Section 5.

\section{Big data in manufacturing systems}

Manufacturing can be defined as the hard segment of an economy which applies resources such as labor, machines, tools, and raw materials in order to produce physical products (Terziovski, 2010). The manufacturing industry contains a huge volume of data created by sensors, electronic devices, and digital machines in factories (Zhong et al., 2015). Manufacturing is a traditional industry which can be highly affected by big data, since the approach for many companies has been changed to operate based on forecasts. Moreover, big data could simplify data visualizations and improve automation applications regarding production design and engineering (Cochran et al., 2016).

Manufacturing plants collect data using different channels such as manufacturing processes, supply chain management systems, and tracking the products sold. Using big data can help to develop new products based on customer needs. Moreover, manufacturers have the opportunity to better plan out their supply chain with a more accurate demand forecast (Nedelcu, 2013). Managers believe that using big data can help diagnose defective products, improve process quality, and better plan supply chains (Nedelcu, 2013).

Manufacturing processes can't be firmly separated from either logistics processes or supply chain management activities. For example, many of the logistics processes in manufacturing plants are performed by tools with radio-frequency identification (RFID) tags, which allows real-time tracking of the products (Dai et al., 2012). Using data analysis on the shop floor enables the system to efficiently implement real-time manufacturing, planning, and scheduling, which is directly affected by both the material delivery time and the real-time information coming from the manufacturing processes. Moreover, analyzing the big data can level the material flow and help the plant manager to better plan space limitations regarding material flow and warehousing operations (Zhong et al., 2015).

There are a lot of process, personnel, and departments data generated during a product's lifecycle. The nine stages of a product's lifecycle were introduced by Tao et al. (2018): product concept, design, raw material purchase, manufacturing, transportation, sale, utilization, after-sale service, and recycle/disposal. In each stage, a lot of data is generated, and by collecting this data for all products, we can have a dataset with big data characteristics. Five areas of big data application in manufacturing are (Benhenni, 2017): 1- using data to forecast a complex process's output; 2 - using data to capture that which is difficult to measure under regular conditions, 3- developing algorithms which can more accurately control the quality and safety of the final product; 4- using image metrology to reduce the amount of human supervision required; and finally, 5- obtaining the optimal time for doing predictive maintenance.

The continued growth of the Internet of Things has also influenced the amount of data available to manufacturing companies. It has been forecasted that by 2025, about 175 trillion gigabytes of data will be 
available, and the manufacturing industry will be the second-fastest-growing sector for data generation, after the healthcare industry (Reinsel et al., 2018). In spite of this huge volume of data - which is generated and kept by manufacturing plants - the number of studies on big data applications in the manufacturing industry is still considerably less than that in the service industries such as finance, information technology, and E-commerce (Weng \& Weng, 2013). However, despite the lack of big data studies in the manufacturing industry, data mining has been used frequently in manufacturing decision making problems (Hanumanthappa \& Sarakutty, 2011).

There are several different areas of manufacturing-including new product development (Niebel et al., 2019; Zhan et al., 2018), smart manufacturing (O'Donovan et al., 2015), cloud-based manufacturing (Kumar et al., 2016), process improvement (Gupta et al., 2020), predictive manufacturing (Lee et al., 2013), and redistributed manufacturing (Zaki et al., 2019)-in which the application of big data analytics can improve system outputs. (Belhadi et al., 2019) studied the major contributions of big data analytics in manufacturing systems by examining several case studies. In order to have a better overview of the recent applications of big data in manufacturing systems, the Thomson Reuters Web of Science was used to categorize the most frequent big data studies in manufacturing. Figure 4 shows the relative frequency of published studies on big data analytics as applied to manufacturing. Studies are categorized based on their research focus in Figure 4, with most categories explained afterwards. It is worth noting that review papers are not being discussed further, since we are studying research contributions in the literature and "review" categories as mentioned in Figure 4 are just there to give further insight. Moreover, the "Marketing" and "Flexibility" categories are not discussed further, since each makes up less than $5 \%$ of the total publications.

\section{Contribution of publications with "big data" in title and "manufacturing" in topic}

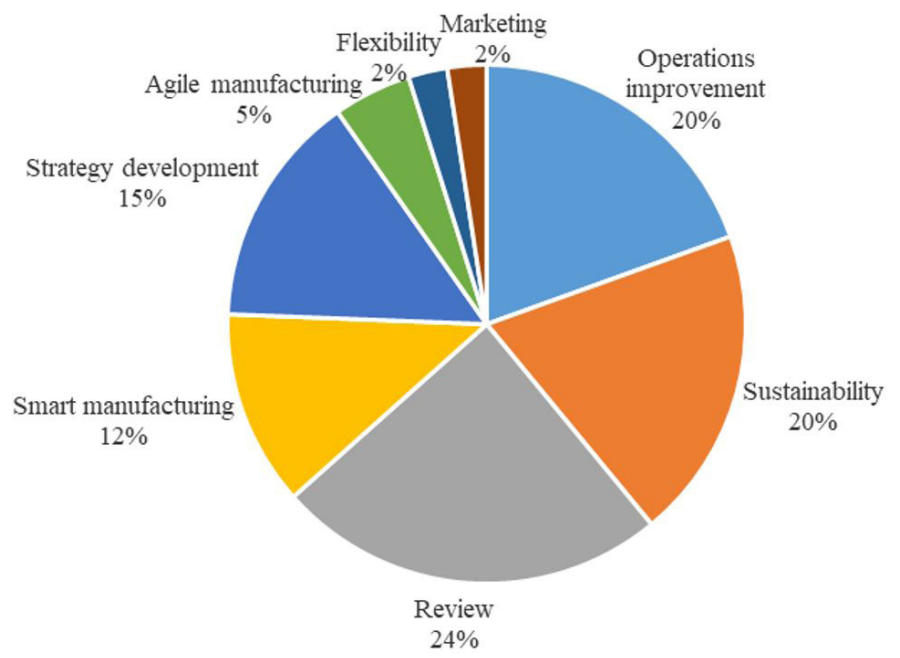

Figure 4. Publication frequencies with "big data" in title and "manufacturing" in topic (Thomson Reuters Web of Science).

\subsection{Operations improvement}

A number of studies show that big data analytics can improve the entire operational performance in manufacturing systems. (Yadegaridehkordi et al., 2018) developed a hybrid approach to study the effect of the adoption of big data analytics on manufacturing companies' performance. (Popovič et al., 2018) showed that big data analytics' capability, along with organizational readiness and certain design factors, could enhance a business's performance. In another study, Guo et al. (2017) applied data visualization and machine learning algorithms to better inform the operations manager of the product's market situation. Some other applications of big data analytics in manufacturing systems are shown by implementing big data analytics in a manufacturing company (Dutta \& Bose, 2015) and using big data to improve the trading performance of emitting companies (Liu et al., 2017). 


\subsection{Sustainability}

Big data can provide useful tools for manufacturers to perform their operations in a sustainable manner, keeping the environment better for future generations. Xu et al. (2019) showed how using the available big data on used products can increase the efficiency of remanufacturing systems and save more resources. Dubey et al. (2016) performed a field study and used the responses by 405 senior managers to develop a framework that could use big data to determine the most important factors for maintaining a sustainable manufacturing system. Lowering service costs, increasing the level of trust between stakeholders, respecting customers' privacy, and increasing data-sharing security are among the benefits that big data analytics may bring to sustainable manufacturing systems (Rehman et al., 2016). In another study, (Huang et al., 2019) developed a theoretical approach to demonstrate the application of big data analytics in the area of production safety management.

The application of big data analytics in Bosch Car Multimedia's (Braga-Portugal) organization (Santos et al., 2017) reviews the challenges of collecting, integrating, storing and processing the data in a manufacturing environment. The Bosch organization study shows the potential opportunity that is created when the volume, variety, and velocity of data is used for sustainable innovations in a future manufacturing environment. In another article, the importance of risk management in developing sustainable manufacturing supply chains was studied (Mani et al., 2017). The paper showed that applying big data analytics in order to mitigate the supply chain's social risk can help improve social and economic sustainability.

\subsection{Smart manufacturing, strategy development, and agile manufacturing}

Big data analytics can be used in smart manufacturing to solve company problems at the speed the business requires. However, there are some organizational and technological barriers that may prevent manufacturing companies from using big data solutions to initiate a smart factory (Li et al., 2019). Big data analytics has been proven to be a valuable tool for manufacturers to help them develop strategies, share data, design predictive models, and connect factories in order to control processes (Kusiak, 2017). A study by Bumblauskas et al. (2017a) studies big data applied to designing a smart maintenance decision support system, which is shown to improve an asset's lifecycle. Liu et al. (2019) used big data analytics for routing order pickup and delivery as well as assigning orders to laundry terminals in smart laundry service enterprises. Big data applications in strategy development and agile manufacturing have also been studied by Opresnik \& Taisch (2015), Waller \& Fawcett (2013), Guha \& Kumar (2018), and Gunasekaran et al. (2018). Ren et al. (2019) reviewed the available research in big data applications that support sustainable smart manufacturing. Agility in a manufacturing system is the capability to better deal with unpredictable events, and deal with them in a business environment that can even turn these events into benefits (Swafford et al., 2008).

Several other studies developed quality research on using big data analytics in the manufacturing field. Some of the selected journal articles and conference proceedings are summarized in Table 1 . The criterion for us consider a paper in the current review is that it must have been cited, on average, more than 10 times each year.

Table 1. High-quality articles using big data in manufacturing processes (Citation count is as of March 2020).

\begin{tabular}{|c|c|c|c|c|c|}
\hline Author / Journal & Contribution & Study approach & $\begin{array}{l}\text { Case study (NA } \\
\text { stands for Not } \\
\text { Applicable) }\end{array}$ & Citation\# & $\begin{array}{l}\text { Future research topic(s) in the } \\
\text { article }\end{array}$ \\
\hline $\begin{array}{l}\text { Lee et al. (2013)/ } \\
\text { Manufacturing letters }\end{array}$ & $\begin{array}{l}\text { Studying the applications } \\
\text { of big data in predictive } \\
\text { manufacturing systems }\end{array}$ & Analytical study & NA & 697 & $\begin{array}{l}\text {-Developing systems to integrate, } \\
\text { manage, and analyze machinery } \\
\text { data during different stages of } \\
\text { machine life cycle }\end{array}$ \\
\hline $\begin{array}{l}\text { O’Donovan et al. } \\
\text { (2015)/Journal of Big } \\
\text { Data }\end{array}$ & $\begin{array}{l}\text { Studying the } \\
\text { requirements for } \\
\text { implementing equipment } \\
\text { maintenance }\end{array}$ & $\begin{array}{l}\text { Analytic field study } \\
\text { / Simulation }\end{array}$ & $\begin{array}{l}\text { DePuy manufacturing } \\
\text { facility in lreland }\end{array}$ & 84 & $\begin{array}{l}\text {-Deployment of big data pipeline } \\
\text { in DePuy } \\
\text {-Using data pipeline to } \\
\text { feed predictive maintenance } \\
\text { applications }\end{array}$ \\
\hline $\begin{array}{l}\text { Dubey et al. (2016)/ } \\
\text { The lnternational } \\
\text { Journal of Advanced } \\
\text { Manufacturing } \\
\text { Technology }\end{array}$ & $\begin{array}{l}\text { Studying the role of } \\
\text { big data in sustainable } \\
\text { manufacturing }\end{array}$ & $\begin{array}{l}\text { Statistical analysis / } \\
\text { Field study }\end{array}$ & NA & 174 & $\begin{array}{l}\text {-Using big data to redefine the } \\
\text { focus of advanced manufacturing } \\
\text { technology } \\
\text {-Using big data innovations like } \\
\text { new materials development }\end{array}$ \\
\hline $\begin{array}{l}\text { Kumar et al. (2016)/ } \\
\text { International Journal } \\
\text { of Production } \\
\text { Research }\end{array}$ & $\begin{array}{l}\text { Solving a data imbalance } \\
\text { problem in cloud-based } \\
\text { manufacturing systems }\end{array}$ & $\begin{array}{l}\text { RHadoop } \\
\text { programming } \\
\text { / MapReduce } \\
\text { framework }\end{array}$ & $\begin{array}{l}\text { Steel plate } \\
\text { manufacturing } \\
\text { company }\end{array}$ & 56 & $\begin{array}{l}\text {-Executing the dissimilar types of } \\
\text { feature } \\
\text { selection approaches } \\
\text {-lmproving performance of } \\
\text { classifiers }\end{array}$ \\
\hline
\end{tabular}


Table 1. Continued..

\begin{tabular}{|c|c|c|c|c|c|}
\hline Author / Journal & Contribution & Study approach & $\begin{array}{l}\text { Case study (NA } \\
\text { stands for Not } \\
\text { Applicable) }\end{array}$ & Citation\# & $\begin{array}{l}\text { Future research topic(s) in the } \\
\text { article }\end{array}$ \\
\hline $\begin{array}{l}\text { Mourtzis et al. (2016)/ } \\
\text { Procedia CIRP }\end{array}$ & $\begin{array}{l}\text { Studying the applications } \\
\text { of the lnternet of Things } \\
\text { in developing industrial } \\
\text { big data }\end{array}$ & Analytic field study & Mould-making industry & 131 & NA \\
\hline $\begin{array}{l}\text { Zhang et al. (2017)/ } \\
\text { Journal of Cleaner } \\
\text { Production }\end{array}$ & $\begin{array}{l}\text { Integrating big data } \\
\text { analytics and service- } \\
\text { driven patterns to create } \\
\text { cleaner manufacturing } \\
\text { and maintenance } \\
\text { processes }\end{array}$ & $\begin{array}{l}\text { Analytical } \\
\text { study / Product life } \\
\text { cycle analysis }\end{array}$ & $\begin{array}{l}\text { Unnamed axial } \\
\text { compressor } \\
\text { manufacturer }\end{array}$ & 170 & $\begin{array}{l}\text {-Using big data analytics to work } \\
\text { out a mathematical model to } \\
\text { discover rules for making cleaner } \\
\text { production decisions } \\
\text {-Representing and visualizing } \\
\text { knowledge gained from big data }\end{array}$ \\
\hline $\begin{array}{l}\text { Zhong et al. (2017)/ } \\
\text { International Journal of } \\
\text { Production Research }\end{array}$ & $\begin{array}{l}\text { Creating a RFID-enabled } \\
\text { intelligent shop floor } \\
\text { using the Internet of } \\
\text { Things }\end{array}$ & $\begin{array}{l}\text { Smart } \\
\text { manufacturing } \\
\text { objects / Wireless } \\
\text { network }\end{array}$ & $\begin{array}{l}\text { Unnamed collaborative } \\
\text { company }\end{array}$ & 177 & $\begin{array}{l}\text {-Developing a mathematical model } \\
\text { to formulate physical internet-based } \\
\text { logistics systems } \\
\text {-Developing a systematic procedure } \\
\text { to examine big data analytical } \\
\text { approaches }\end{array}$ \\
\hline $\begin{array}{l}\text { Gunasekaran et al. } \\
\text { (2018)/International } \\
\text { Journal of Production } \\
\text { Research }\end{array}$ & $\begin{array}{l}\text { Studying the role } \\
\text { of big data in agile } \\
\text { manufacturing }\end{array}$ & Analytic field study & $\begin{array}{l}\text { Four organizations in } \\
\text { United Kingdom }\end{array}$ & 46 & $\begin{array}{l}\text {-Studying the applications of the } \\
\text { Internet of Things, Industry } 4, \\
\text { and Blockchain technologies in } \\
\text { developing agile manufacturing } \\
\text { systems }\end{array}$ \\
\hline $\begin{array}{l}\text { Moktadir et al. (2019)/ } \\
\text { Computers \& Industrial } \\
\text { Engineering }\end{array}$ & $\begin{array}{l}\text { Studying the barriers } \\
\text { to applying big data } \\
\text { analytics in manufacturing } \\
\text { supply chains }\end{array}$ & $\begin{array}{l}\text { Delphi-based } \\
\text { analytic hierarchy } \\
\text { process (AHP) / } \\
\text { Sensitivity analysis }\end{array}$ & $\begin{array}{l}\text { Five manufacturing } \\
\text { companies in } \\
\text { Bangladesh }\end{array}$ & 20 & $\begin{array}{l}\text {-Using international data to examine } \\
\text { big data analytics barriers } \\
\text {-Utilizing the extensions of AHP } \\
\text { method to further explore the } \\
\text { direction of the studied research }\end{array}$ \\
\hline $\begin{array}{l}\text { Popovič et al. (2018)/ } \\
\text { Information Systems } \\
\text { Frontiers }\end{array}$ & $\begin{array}{l}\text { Using a qualitative } \\
\text { approach to study the } \\
\text { impact of big data } \\
\text { analytics in manufacturing } \\
\text { sector }\end{array}$ & $\begin{array}{l}\text { Comparative analytic } \\
\text { field study }\end{array}$ & $\begin{array}{l}\text { Three manufacturing } \\
\text { companies in Europe }\end{array}$ & 70 & $\begin{array}{l}\text {-Studying the impact of big data } \\
\text { analytics on low-performing firms } \\
\text {-Studying failed cases instead of } \\
\text { successful cases }\end{array}$ \\
\hline $\begin{array}{l}\text { Tao et al. (2018)/ } \\
\text { The International } \\
\text { Journal of Advanced } \\
\text { Manufacturing } \\
\text { Technology }\end{array}$ & $\begin{array}{l}\text { Developing a method } \\
\text { using a digital twin } \\
\text { to design a product, } \\
\text { manufacture, and } \\
\text { service it }\end{array}$ & $\begin{array}{l}\text { Product life cycle } \\
\text { analysis }\end{array}$ & $\begin{array}{l}\text { Author created } \\
\text { applications as case }\end{array}$ & 434 & $\begin{array}{l}\text {-Digital twin data construction and } \\
\text { management } \\
\text {-Developing smart service analysis } \\
\text { based on digital twin data }\end{array}$ \\
\hline $\begin{array}{l}\text { Dubey et al. (2019a)/ } \\
\text { Technological } \\
\text { Forecasting and Social } \\
\text { Change }\end{array}$ & $\begin{array}{l}\text { Studying the impact of } \\
\text { big data analytics on } \\
\text { the social performance } \\
\text { and environmental } \\
\text { performance of } \\
\text { manufacturing companies }\end{array}$ & $\begin{array}{l}\text { Partial Least Squares } \\
\text { / Hypothesis testing }\end{array}$ & $\begin{array}{l}\text { Sample of } 205 \\
\text { manufacturing } \\
\text { companies in India }\end{array}$ & 84 & $\begin{array}{l}\text {-Studying the exact role of the } \\
\text { flexibility or control orientation on } \\
\text { big data and predictive analytics } \\
\text { on manufacturers' social and } \\
\text { environmental performance }\end{array}$ \\
\hline $\begin{array}{l}\text { Moktadir et al. (2019)/ } \\
\text { Computers \& Industrial } \\
\text { Engineering }\end{array}$ & $\begin{array}{l}\text { Studying the critical } \\
\text { barriers to the adoption } \\
\text { of big data analytics in } \\
\text { manufacturing systems }\end{array}$ & $\begin{array}{l}\text { Delphi-based } \\
\text { analytic hierarchy } \\
\text { process }\end{array}$ & $\begin{array}{l}\text { Five manufacturing } \\
\text { companies in } \\
\text { Bangladesh }\end{array}$ & 20 & $\begin{array}{l}\text {-Using international data in the } \\
\text { same study } \\
\text {-Using other decision-making } \\
\text { techniques to study the interaction } \\
\text { among barriers }\end{array}$ \\
\hline $\begin{array}{l}\text { (Raut et al., 2019) } \\
\text { / Journal of cleaner } \\
\text { production }\end{array}$ & $\begin{array}{l}\text { Using big data analytics } \\
\text { to improve manufacturing } \\
\text { sustainability in terms of } \\
\text { operations management }\end{array}$ & $\begin{array}{l}\text { Structural equation } \\
\text { modelling-artificial } \\
\text { neural network }\end{array}$ & $\begin{array}{l}\text { Survey data from } 316 \\
\text { Indian experts }\end{array}$ & 16 & $\begin{array}{l}\text {-Studying this same issue in other } \\
\text { geographical locations besides India } \\
\text {-Studying other technologies that } \\
\text { firms may adopt for sustainable } \\
\text { purposes }\end{array}$ \\
\hline
\end{tabular}

\section{Big data in supply chain management (other than manufacturing and logistics)}

A supply chain is a sequence or network of suppliers, manufacturers, transporters, warehouses, retailers, and customers. Supply chain management is trying to manage the flows of funds, information, and products in a supply chain to ensure a high level of product availability and service to the customer with the lowest possible cost (Chopra \& Meindl, 2007). These days, there are so many records generated by transactions between the suppliers and the purchasers. Choi et al. (2018) discussed the application of big data techniques and strategies in various supply chain management topics such as forecasting, revenue management, risk analysis, etc. and provided examples from top branded firms. Even with all the increased usage of big data in supply chain management, there are still several managers that don't apply big data analytics in their decision-making processes. 
It is an important issue to consider the availability of data when developing decision models in a system (Kaur \& Singh, 2018). There are three major flows in each supply chain: information, material, and money. Using data analysis, supply chain managers are able to monitor these flows and apply the results in order to better accomplish their jobs (Arunachalam et al., 2018). Researchers believe that information assumes the role of an invisible string between the supply chain members in order to achieve the most efficient cooperation and make the right decisions at the right time, apply the resources at an optimized level, and direct all of the supply chain activities in the right direction (Biswas \& Sen, 2016).

The convergence of certain factors has recently increased the desire to use data analysis in supply chains (lttmann, 2015): 1- the increased volume of available data in supply chains; 2 - the lower cost of data storage compared to past years'; 3- powerful hardware which can speed up data analysis; 4- continuous access from mobile data; 5- powerful tools which simplify working with data; and 6- methods which can graphically show a large amount of data (advanced visualization). Available information in a supply chain is mostly regarding customers, sales, markets, service level requirements, demand forecasts, inventory, capacity deployment, quality control, human resources, skills levels, logistics, resources, warehouse planning, and pricing (Biswas \& Sen, 2016).

Big data enables companies to better evaluate their suppliers and control the procurement process (Sanders, 2014). Using big data, companies are also capable of simulating their supply chains. Simulation allows for the possibility of finding bottlenecks, virtually running the production process in different locations, and examining prototypes (Kynast \& Marjanovic, 2016).

Big data can improve the supply chain throughput by increasing the visibility (Barratt \& Oke, 2007), resilience, robustness (Brandon-Jones et al., 2014), and organizational performance (Schoenherr \& Speier-Pero, 2015) of the supply chain. Big data also improves the knowledge management in supply chains, which can increase the supply chain throughput by improving product development. Moreover, big data can positively affect demand predictions, inventory management, production and service scheduling, and product development in a supply chain (Lin, 2016).

Supply chains benefit from big data because of the cycle time reduction, cross-functional views, decision-making process improvement, and supply chain performance optimization. For example, big data can reduce the bullwhip effect in a supply chain by reducing the uncertainties of the future demand (Militaru et al., 2015). Using big data analytics has been shown to be useful in improving the logistics and supply chain management processes (Arunachalam et al., 2018; Brinch et al., 2018; Dubey et al., 2019b; El-Kassar \& Singh, 2019). The Thomson Reuters Web of Science is used to study various contributions in the supply chain management and logistics fields by using big data analytics. Figure 5 shows the relative frequency of the published works in big data analytics applications with regards to logistics and supply chain management. Studies are categorized

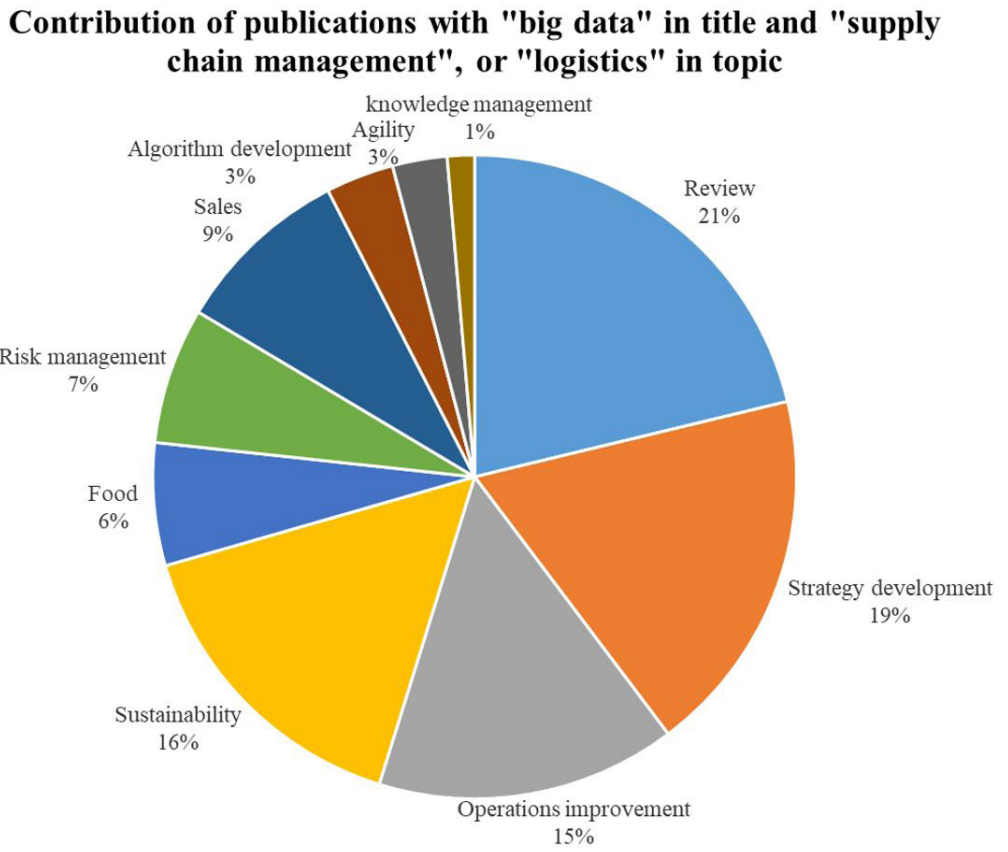

Figure 5. Publication frequencies with "big data" in title and "supply chain management" or "logistics" in topic (Thomson Reuters Web of Science). 
based on their research focus in Figure 5; most categories are explained in more detail afterwards. It is worth nothing, however, that review papers are not discussed further, since we are studying research contributions in the literature; the "review" category is mentioned in Figure 5 just to help give more insight. Moreover, the "Knowledge Management", "Agility", and "Algorithm Development" categories are not further discussed, since each includes less than $5 \%$ of the publications.

\subsection{Strategy development}

Management's decision to use big data analytics in a company would be a strategic one. Management commitment positively affects the level of accepting big data analytics in a company (Gunasekaran et al., 2017). Using big data analytics lets the manager have access to analysis which based on dynamic data, and can make the supply chain more competitive (Chen et al., 2015). Applying big data analytics to planning, decision making, and supply chain coordination and control can improve the preparedness, alertness, and agility of the supply chains in question (Mandal, 2019). The aspect of value creation by big data has not been studied often in supply chain management literature. Therefore, Brinch (2018) studied the value discovery, creation, and capture that can be achieved using big data analytics in a business supply chain.

All benefits considered, there still is not enough empirical research that applies big data analytics to supply chain management, so there is a lack of ability to adopt an informed strategy just by comparing different methods (Kache \& Seuring, 2017). Investing money in the required hardware and software to apply big data analytics may affect the strategies of a supply chain. As for training, our educational system can train a good number of data scientists, but may have ignored the managerial abilities of these data scientists in many cases (Carillo, 2017). As a consequence, converting the available data into applicable knowledge which can mitigate supply chain risks is still an obstacle for many supply chains (Bumblauskas et al., 2017b).

\subsection{Operations improvement}

Dealing with varying numbers of suppliers, manufacturers, logistic providers, etc. creates big data sets that can be used for optimization projects in a supply chain. Big data analytics improves demand forecasts, reduces the safety stock, and improves a supplier's management practices (Roßmann et al., 2018). It has been shown that big data predictive analytics can be combined with other methods such as enterprise resource planning to improve the performance of supply chains (Gupta et al., 2019c). Oncioiu et al. (2019) studied the role of big data analytics applications in improving Romanian supply chain companies' performance and implementing assessment processes. Big data analytics has also been used by Boone et al. (2017) to improve the practices of service parts management.

In another study, Hofmann (2017) shows that the velocity of big data can be used to reduce the bullwhip effect (increasing the safety stock levels in upward echelons) in supply chains. Working with omni-channel supply chains generates a huge amount of data from different sources. Big data analytics can make more accurate sales predictions in different channels and develop optimal delivery plans to minimize transportation costs (Lee, 2017). In another application, sharing the data through a big data framework can reduce the uncertainty cost in a supply chain (Liu \& Yi, 2016).

\subsection{Sustainability}

Another application of big data analytics in supply chains can be the optimization and adjustment of the operations based on sustainable objectives. Big data can improve the environmental, financial, and operational management of the supply chain in order to help combat climate change (Seles et al., 2018). Badiezadeh et al. (2018) developed a network data envelopment analysis with big data in order to help assess the performance of sustainable supply chain management. Open access to big data can facilitate innovation, create resilient supply chains, and improve the performance of the distribution network (Weerakkody et al., 2017). Liu (2019) demonstrates how applying big data analytics to the targeted advertising of products can reduce the carbon emissions in a supply chain.

It is worth noting that using big data analytics is not beneficial in all supply chains. There are several barriers that may interact together and prevent big data analytics from establishing a sustainable system (Shukla \& Mattar, 2019). Cheng et al. (2018) considers a sustainable supply chain with a manufacturer and a retailer and shows that the proficiency in big data analytics depends on the service level adopted by the retailer. Available big data from transportation and logistic provider companies can be used to satisfy delivery requirements 
while also keeping in mind carbon emission constraints (Ji \& Sun, 2017; Zhao et al., 2017). In another study, the application of Big data analytics in enabling the resilience of supply chains after disasters was studied by (Papadopoulos et al., 2017), where they used the example of Nepal to prove their analysis.

\subsection{Food supply chains}

The lack of information in food supply chains can bring about huge costs in the forms of deterioration and waste. Accordingly, using the information excluded from big data analytics is gaining more attention from the decision makers in food supply chains. Big data analytics has applications in agricultural supply chain management, farm management, food sustainability assurance, consumer demand management, new product development, and food safety (Coble et al., 2018; Giagnocavo et al., 2017; Jagtap \& Duong, 2019; Shukla \& Tiwari, 2017; Wolfert et al., 2017). Ji \& Tan (2017) considers five major benefits of using big data in food supply chain management: 1 - data sharing over supply chain echelons; 2 - doing experiments to find frauds and anomalies in the supply chain; 3- accurate clustering of customers in order to target the marketing of each cluster; 4- developing automated algorithms to support the decision-making processes; and 5- developing new products, services, and business models.

Big data analytics was used by (Liu, 2017) to develop new e-commerce methods for marketing fresh products with a short shelf life by keeping in mind the critical aspects of humidity and temperature. In another research paper, Mishra et al. (2017) used social media big data to determine factors that influence customers' beef purchasing decisions. They believe that the available unstructured big data in social media can help businesses to design their supply chain to be more consumer centric. Big data applications have also been developed for cold chains (temperature-controlled supply chains). However, there is an important lack of understanding regarding what data in a cold chain should be collected, and what is the appropriate method to collect and analyze that data (Chaudhuri et al., 2016).

\subsection{Risk management}

Any supply chain that is dealing with uncertainties in its decision-making processes is using risk management methods at some level. Risk is one of the consequences of a lack of information, and big data can be applied to reduce this lack of information. In the context of logistics processes, transportation risk can be defined as the deviation from the estimated delivery time. Big data analytics can be applied to predict these delivery time deviations, as well as prevent transportation risks such as missing cargo flights (Shang et al., 2017). Engelseth \& Wang (2018) used big data analytics to manage the risks in long-linked supply chains. They used an analytical framework to mitigate the risks of a case study that looked at machine parts imported from China to Norway.

The establishment of big data analytics could resolve bargain issues between a supplier and a retailer. Tsao (2017) used big data analytics and game theory to show the way that a supplier and a retailer could determine the period in which to use their credit in order to minimize their risk of defaulting. A type of common risk is that of hazardous materials and waste in closed supply chains (supply chains with remanufacturers and recyclers) (Deleris et al., 2004; Van Asselt et al., 2017). Big data analytics has also proven to be useful in recognizing powerful demand signals and minimizing the negative environmental impacts of remanufacturing (Niu \& Zou, 2017; Wu et al., 2017).

\subsection{Marketing and sales}

Big data analytics can help inform marketing managers of current trends in product sales beyond simply the demand forecasts. For example, product reviews can be approved more easily to help influence sales performance in many studies (Li et al., 2016). The impact of big data analytics on improving sales forecasting was studied in an analytical review by Boone et al. (2019). Sagaert et al. (2018) shows that using big data analytics can improve the transparency of market dynamics to sales managers. Using big data analytics in the case study of a tire company could improve forecasting accuracy by $16.1 \%$ over the traditional method (Sagaert et al., 2018). Moreover, Li et al. (2018) showed that managing a demand chain with big data and electronic commerce works much better than traditional methods of supply chain management.

Using product-in-use data has been proven to reduce the uncertainty for aftermarket (spare parts) demand planning (Andersson \& Jonsson, 2018). Gawankar et al. (2020) studied the impact of new technologies-such as the Internet of Things and big data analytics-on the retail environment in India. They found that the retailing industry in India is eager to use new technologies in the retailing environment that they call "Retail 4.0" in their 
study. Big data analytics was also used by (Liu \& Yi, 2017) to show the correlation between the price and the products' environment friendliness degree. It shows that the available data can used for targeted advertisements in a supply chain's green environment. Another study in big data pricing application was done by (Liu, 2017), in which he considered the data company to be an echelon in the supply chain, and determined its benefits using the Stackelberg game.

Analyzing social media data can help supply chains increase their number of customers in the system through personalized services. Companies can analyze social networks, mobile, and web data to track the way that a customer wants to use the product (Agrahri et al., 2017). On the other hand, Aloysius et al. (2018) survey of a group of retail store customers showed that many people have concerns about how much of their personal information is collected, which can negatively affect the store's image.

Some of the selected journal articles regarding big data applications in supply chain management are summarized in Table 2.

Table 2. High-quality articles using big data in supply chain management practices (Citation count is as of March 2020).

\begin{tabular}{|c|c|c|c|c|c|}
\hline Author / Journal & Contribution & $\begin{array}{c}\text { Study } \\
\text { approach }\end{array}$ & $\begin{array}{l}\text { Case study (NA stands } \\
\text { for Not Applicable) }\end{array}$ & Citation\# & Future research topic(s) in the article \\
\hline $\begin{array}{l}\text { Hazen et al. (2014)/ } \\
\text { International Journal of } \\
\text { Production Economics }\end{array}$ & $\begin{array}{l}\text { Studying the importance } \\
\text { of data quality in supply } \\
\text { chain management } \\
\text { decisions }\end{array}$ & $\begin{array}{l}\text { Statistical } \\
\text { process control } \\
\text { / Field study }\end{array}$ & $\begin{array}{l}\text { Remanufacturing } \\
\text { company for jet } \\
\text { engines and related } \\
\text { components for military } \\
\text { aircraft }\end{array}$ & 527 & $\begin{array}{l}\text {-Developing new methods for controlling } \\
\text { data }\end{array}$ \\
\hline $\begin{array}{l}\text { Chen et al. (2015)/ } \\
\text { Journal of Management } \\
\text { Information Systems }\end{array}$ & $\begin{array}{l}\text { Studying the role of big } \\
\text { data analytics in value } \\
\text { creation and competitive } \\
\text { advantage }\end{array}$ & $\begin{array}{l}\text { Technological, } \\
\text { organizational, } \\
\text { and } \\
\text { environmental } \\
\text { (TOE) } \\
\text { framework }\end{array}$ & $\begin{array}{l}\text { Collected data from } \\
\text { supply chain executives } \\
\text { through a questionnaire }\end{array}$ & 192 & $\begin{array}{l}\text {-Examining the influence of firm-level } \\
\text { employment of big data analytics on } \\
\text { organizational performance } \\
\text {-Examining the intervening variables } \\
\text { between organizational IT practices and } \\
\text { performance outcomes }\end{array}$ \\
\hline $\begin{array}{l}\text { Tan et al. (2015)/ } \\
\text { International Journal of } \\
\text { Production Economics }\end{array}$ & $\begin{array}{l}\text { Providing firms an } \\
\text { analytic infrastructure } \\
\text { to combine their } \\
\text { competence sets }\end{array}$ & $\begin{array}{l}\text { Deduction } \\
\text { graph } \\
\text { technique }\end{array}$ & $\begin{array}{l}\text { SPEC company, a } \\
\text { leading eyeglasses } \\
\text { manufacturer in China }\end{array}$ & 252 & $\begin{array}{l}\text {-Testing the contributed approach on other } \\
\text { supply chains to determine its general } \\
\text { applicability } \\
\text {-Simplifying the contributed mathematical } \\
\text { approach }\end{array}$ \\
\hline $\begin{array}{l}\text { Giannakis \& Louis } \\
\text { (2016)/Journal of } \\
\text { Enterprise lnformation } \\
\text { Management }\end{array}$ & $\begin{array}{l}\text { Developing a big data } \\
\text { analytics system that } \\
\text { exerts autonomous } \\
\text { corrective control actions } \\
\text { in a supply chain }\end{array}$ & $\begin{array}{l}\text { Analytical study } \\
\text { / Supply chain } \\
\text { agility theories }\end{array}$ & NA & 77 & $\begin{array}{l}\text {-Studying the application of an agent-based } \\
\text { technology in supply chain sustainability } \\
\text {-Studying the influence of the attributes } \\
\text { of supply chain managers on the } \\
\text { implementation of agent-based technology } \\
\text { in decision making }\end{array}$ \\
\hline $\begin{array}{l}\text { Prasad et al. (2018)/ } \\
\text { Annals of Operations } \\
\text { Research }\end{array}$ & $\begin{array}{l}\text { Developing a model } \\
\text { to connect big data } \\
\text { analytics to superior } \\
\text { humanitarian outcomes }\end{array}$ & $\begin{array}{l}\text { Resource } \\
\text { dependence } \\
\text { theory }\end{array}$ & $\begin{array}{l}\text { Three focal non- } \\
\text { governmental } \\
\text { organizations' supply } \\
\text { network in lndia }\end{array}$ & 42 & $\begin{array}{l}\text {-Doing research to clearly identify stages } \\
\text { regarding big data attributes } \\
\text {-Examining the scenarios of non-linear } \\
\text { patterns emanating from distributed supply } \\
\text { chain networks }\end{array}$ \\
\hline $\begin{array}{l}\text { Richey Junior et al. } \\
\text { (2016)/International } \\
\text { Journal of Physical } \\
\text { Distribution \& Logistics } \\
\text { Management }\end{array}$ & $\begin{array}{l}\text { Developing a framework } \\
\text { in which supply chain } \\
\text { managers can use big } \\
\text { data }\end{array}$ & $\begin{array}{l}\text { Native category } \\
\text { approach }\end{array}$ & $\begin{array}{l}\text { Interviewing } 27 \text { supply } \\
\text { chain experts in } 6 \\
\text { countries }\end{array}$ & 68 & $\begin{array}{l}\text {-Developing unbiased managerial guidance } \\
\text { for using big data analytics in supply chain } \\
\text { management }\end{array}$ \\
\hline $\begin{array}{l}\text { Gunasekaran et al. } \\
\text { (2017)/Journal of } \\
\text { Business Research }\end{array}$ & $\begin{array}{l}\text { Studying the impact of } \\
\text { big data and predictive } \\
\text { analytics on supply chain } \\
\text { performance }\end{array}$ & $\begin{array}{l}\text { Statistical } \\
\text { analysis / Field } \\
\text { study }\end{array}$ & $\begin{array}{l}\text { E-mail survey of a } \\
\text { sample of } \\
\text { companies in India }\end{array}$ & 279 & $\begin{array}{l}\text {-lnvestigating top managers' commitment } \\
\text { towards developing big data predictive } \\
\text { analytics capabilities }\end{array}$ \\
\hline $\begin{array}{l}\text { Kache \& Seuring } \\
\text { (2017)/International } \\
\text { Journal of Operations } \\
\text { \& Production } \\
\text { Management }\end{array}$ & $\begin{array}{l}\text { Investigating the impacts } \\
\text { of big data analytics on } \\
\text { information usage in a } \\
\text { supply chain }\end{array}$ & $\begin{array}{l}\text { Delphi survey } \\
\text { / Statistical } \\
\text { analysis }\end{array}$ & $\begin{array}{l}\text { Collect data from } \\
15 \text { experts by } \\
\text { questionnaire }\end{array}$ & 195 & $\begin{array}{l}\text {-Studying the constituents of a big data } \\
\text { ecosystem as keys for optimal supply chain } \\
\text { productivity }\end{array}$ \\
\hline $\begin{array}{l}\text { Roßmann et al. } \\
\text { (2018)/Technological } \\
\text { Forecasting and Social } \\
\text { Change }\end{array}$ & $\begin{array}{l}\text { Studying expert } \\
\text { assessments of big data } \\
\text { analytics applications } \\
\text { in supply chain } \\
\text { management }\end{array}$ & $\begin{array}{l}\text { Delphi survey / } \\
\text { Fuzzy c-means } \\
\text { clustering }\end{array}$ & $\begin{array}{l}\text { Interview with } 73 \\
\text { experts }\end{array}$ & 38 & $\begin{array}{l}\text {-Interviewing other fields' experts } \\
\text {-Studying the impact of potential } \\
\text { technological applications on social dynamics } \\
\text { in supply chain management }\end{array}$ \\
\hline $\begin{array}{l}\text { Choi (2018)/ } \\
\text { Transportation Research } \\
\text { Part E }\end{array}$ & $\begin{array}{l}\text { Studying the impact of } \\
\text { social media comments } \\
\text { on quick response supply } \\
\text { chains in fashion }\end{array}$ & $\begin{array}{l}\text { Analytical } \\
\text { mathematical } \\
\text { modeling / } \\
\text { Newsvendor } \\
\text { model }\end{array}$ & NA & 30 & $\begin{array}{l}\text {-lncorporate the correlation of consumer } \\
\text { voices and a product's demand } \\
\text {-Studying the impact of a government's role } \\
\text { in local sourcing and emissions taxes on a } \\
\text { supplier-market relationship }\end{array}$ \\
\hline
\end{tabular}


Table 2. Continued...

\begin{tabular}{|c|c|c|c|c|c|}
\hline Author / Journal & Contribution & $\begin{array}{c}\text { Study } \\
\text { approach }\end{array}$ & $\begin{array}{l}\text { Case study (NA stands } \\
\text { for Not Applicable) }\end{array}$ & Citation\# & Future research topic(s) in the article \\
\hline $\begin{array}{l}\text { Coble et al. (2018)/ } \\
\text { Applied Economic } \\
\text { Perspectives and Policy }\end{array}$ & $\begin{array}{l}\text { Studying the challenges } \\
\text { and opportunities of } \\
\text { using big data analytics } \\
\text { in an agricultural value } \\
\text { chain }\end{array}$ & Analytical study & NA & 65 & $\begin{array}{l}\text {-Studying data ownership rules in an } \\
\text { agriculture supply chain } \\
\text {-Developing access to technology } \\
\text { infrastructure for rural areas }\end{array}$ \\
\hline $\begin{array}{l}\text { Dubey et al., 2019)/ } \\
\text { Management Decision }\end{array}$ & $\begin{array}{l}\text { Studying how to use big } \\
\text { data analytics to improve } \\
\text { the agility of a supply } \\
\text { chain }\end{array}$ & $\begin{array}{l}\text { Statistical } \\
\text { analysis / } \\
\text { Hypotheses } \\
\text { tests }\end{array}$ & $\begin{array}{l}\text { Collected data from } \\
173 \text { experts by } \\
\text { questionnaire }\end{array}$ & 46 & $\begin{array}{l}\text {-Using other theoretical perspectives to study } \\
\text { the effect of big data analytics on the agility } \\
\text { of a supply chain } \\
\text {-Using case-based methods instead of } \\
\text { survey-based research }\end{array}$ \\
\hline $\begin{array}{l}\text { Dubey et al. }(2018 \mathrm{~b}) / \\
\text { The International } \\
\text { Journal of Logistics } \\
\text { Management }\end{array}$ & $\begin{array}{l}\text { Studying big data } \\
\text { predictive analytics' } \\
\text { impact on coordination } \\
\text { and visibility in } \\
\text { humanitarian supply } \\
\text { chains }\end{array}$ & $\begin{array}{l}\text { Least squares } \\
\text { regression / } \\
\text { Hypothesis tests }\end{array}$ & $\begin{array}{l}\text { Survey responses from } \\
205 \text { International } \\
\text { Non-Government } \\
\text { Organizations }\end{array}$ & 26 & $\begin{array}{l}\text {-Considering country culture and/or supply } \\
\text { base complexity in a predictive model } \\
\text {-Applying agent-based simulation methods }\end{array}$ \\
\hline $\begin{array}{l}\text { Irani et al. (2018)/ } \\
\text { Computers \& } \\
\text { Operations Research }\end{array}$ & $\begin{array}{l}\text { Studying organizational } \\
\text { factors that impact the } \\
\text { amount of waste in a } \\
\text { food supply chain }\end{array}$ & $\begin{array}{l}\text { Fuzzy cognitive } \\
\text { map / } \\
\text { Simulation }\end{array}$ & $\begin{array}{l}\text { Data from surveying } \\
34 \text { stakeholders in food } \\
\text { industry in Qatar }\end{array}$ & 21 & $\begin{array}{l}\text {-Use Delphi method to involve a wider set of } \\
\text { participants } \\
\text {-Develop the same approach in countries } \\
\text { besides Qatar }\end{array}$ \\
\hline $\begin{array}{l}\text { Jeble et al. (2018)/The } \\
\text { International Journal of } \\
\text { Logistics Management }\end{array}$ & $\begin{array}{l}\text { Studying the impact of } \\
\text { big data and predictive } \\
\text { analytics on sustainable } \\
\text { business development }\end{array}$ & $\begin{array}{l}\text { Resource-based } \\
\text { view logic / } \\
\text { Contingency } \\
\text { theory }\end{array}$ & $\begin{array}{l}\text { Survey data from } 205 \\
\text { individuals in auto } \\
\text { components industry }\end{array}$ & 40 & $\begin{array}{l}\text {-Studying the actual impact of big data and } \\
\text { predictive analytics on a business firm rather } \\
\text { than just the perception of the impact } \\
\text {-Explore data that can be more generalized }\end{array}$ \\
\hline $\begin{array}{l}\text { Lai et al. (2018)/The } \\
\text { International Journal of } \\
\text { Logistics Management }\end{array}$ & $\begin{array}{l}\text { Studying the factors that } \\
\text { determine the adoption } \\
\text { of big data analytics in } \\
\text { supply chains }\end{array}$ & $\begin{array}{l}\text { Technology- } \\
\text { organization- } \\
\text { environment } \\
\text { (TOE) } \\
\text { framework }\end{array}$ & $\begin{array}{l}\text { Survey data from } 210 \\
\text { Chinese } 1 T \text { managers } \\
\text { and business analysts }\end{array}$ & 28 & $\begin{array}{l}\text {-Increase the environmental safety of big } \\
\text { data } \\
\text {-Studying the other factors that may affect } \\
\text { the adoption of big data analytics, such as } \\
\text { supply chain scale and delivery complexity }\end{array}$ \\
\hline $\begin{array}{l}\text { Lau et al. (2018)/ } \\
\text { Production } \\
\text { and Operations } \\
\text { Management }\end{array}$ & $\begin{array}{l}\text { Using consumer social } \\
\text { media comments for } \\
\text { sales forecasting }\end{array}$ & $\begin{array}{l}\text { Parallel } \\
\text { sentiment } \\
\text { analysis / } \\
\text { Machine } \\
\text { learning }\end{array}$ & $\begin{array}{l}\text { Consumer comments } \\
\text { datasets in English and } \\
\text { Chinese }\end{array}$ & 31 & $\begin{array}{l}\text {-Combining parallel topic models } \\
\text { with lifelong learning strategies } \\
\text {-Examining parallel ensemble models for } \\
\text { better sales forecasting }\end{array}$ \\
\hline $\begin{array}{l}\text { Gupta et al. (2019b)/ } \\
\text { Technological } \\
\text { Forecasting and Social } \\
\text { Change }\end{array}$ & $\begin{array}{l}\text { Using big data analytics } \\
\text { to support data-driven } \\
\text { decision making in } \\
\text { circular economical } \\
\text { supply chains }\end{array}$ & $\begin{array}{l}\text { Stakeholder } \\
\text { perspective } \\
\text { on circular } \\
\text { economy }\end{array}$ & $\begin{array}{l}\text { Interview data from } 10 \\
\text { expert employees }\end{array}$ & 19 & $\begin{array}{l}\text {-Using larger empirical data for this study } \\
\text {-Studying inter-organizational relationships, } \\
\text { intra-organizational dynamics, and } \\
\text { informational privacy issues in supply chains }\end{array}$ \\
\hline $\begin{array}{l}\text { Lamba \& Singh } \\
(2019) / \text { Technological } \\
\text { Forecasting and Social } \\
\text { Change }\end{array}$ & $\begin{array}{l}\text { Using big data analytics } \\
\text { to study a supplier's } \\
\text { selection and lot- } \\
\text { sizing problem under } \\
\text { carbon cap-and-trade } \\
\text { regulations }\end{array}$ & $\begin{array}{l}\text { Mixed integer } \\
\text { non-linear } \\
\text { program }\end{array}$ & $\begin{array}{l}\text { Experimental problem } \\
\text { sets }\end{array}$ & 15 & $\begin{array}{l}\text {-Developing heuristics that can obtain the } \\
\text { solution via a faster method } \\
\text {-Studying the same model's behavior under } \\
\text { various carbon emission regulations }\end{array}$ \\
\hline $\begin{array}{l}\text { Lamba et al. (2019)/ } \\
\text { Computers \& Industrial } \\
\text { Engineering }\end{array}$ & $\begin{array}{l}\text { Studying a supplier } \\
\text { selection and lot-sizing } \\
\text { problem in dynamic } \\
\text { supply chains }\end{array}$ & $\begin{array}{l}\text { Mixed integer } \\
\text { non-linear } \\
\text { program }\end{array}$ & $\begin{array}{l}\text { A randomly generated } \\
\text { dataset }\end{array}$ & 23 & $\begin{array}{l}\text {-Studying the stochastic demand with the } \\
\text { same problem settings } \\
\text {-Focusing on the veracity and value } \\
\text { characteristics of big data }\end{array}$ \\
\hline $\begin{array}{l}\text { Shen et al. (2019)/ } \\
\text { Technological } \\
\text { Forecasting and Social } \\
\text { Change }\end{array}$ & $\begin{array}{l}\text { Using big data analytics } \\
\text { to find if a retailer must } \\
\text { sell green or non-green } \\
\text { products first, according } \\
\text { to shelf space limitations }\end{array}$ & $\begin{array}{l}\text { Bayesian } \\
\text { analysis }\end{array}$ & NA & 19 & $\begin{array}{l}\text {-Studying incentive contracts in order to } \\
\text { achieve a coordinated supply chain } \\
\text {-Studying the role of government } \\
\text { interventions on selling green products } \\
\text {-Studying this case with enough shelf space } \\
\text { for both green and non-green products }\end{array}$ \\
\hline $\begin{array}{l}\text { Singh \& El-Kassar } \\
\text { (2019)/Journal of } \\
\text { Cleaner Production }\end{array}$ & $\begin{array}{l}\text { Studying the impact of } \\
\text { the integration of big } \\
\text { data with green supply } \\
\text { chain management } \\
\text { and human resource } \\
\text { management on a firms' } \\
\text { sustainability }\end{array}$ & $\begin{array}{l}\text { Statistical } \\
\text { analysis / } \\
\text { Hypotheses } \\
\text { testing }\end{array}$ & $\begin{array}{l}\text { Survey data from } 215 \\
\text { employees in Saudi } \\
\text { Arabia, the } \\
\text { United Arab Emirates, } \\
\text { Egypt, and Lebanon }\end{array}$ & 40 & $\begin{array}{l}\text {-Using the same research framework of this } \\
\text { study with multisource and/or multi-time } \\
\text { datasets } \\
\text {-Using mixed methods instead of } \\
\text { quantitative data within the same research } \\
\text { framework }\end{array}$ \\
\hline $\begin{array}{l}\text { Yu et al. (2019)/ } \\
\text { International Journal of } \\
\text { Forecasting }\end{array}$ & $\begin{array}{l}\text { Using Google trends } \\
\text { to forecast the oil } \\
\text { consumption in an oil } \\
\text { supply chain }\end{array}$ & $\begin{array}{l}\text { Cointegration } \\
\text { tests / Granger } \\
\text { causality } \\
\text { analysis }\end{array}$ & $\begin{array}{l}\text { Data from Google } \\
\text { trends }\end{array}$ & 38 & $\begin{array}{l}\text {-Considering the dynamic between Google } \\
\text { trends and oil consumption over time } \\
\text {-Introducing other types of big data, such as } \\
\text { social networks, to the proposed model }\end{array}$ \\
\hline
\end{tabular}




\section{Big data in logistics}

Since the 1980s, optimizing resource consumption and outsourcing non-specialized activities such as logistics processes had been a major practice in most businesses. Today, logistics is a critical part of both the manufacturing and service industries (Briggs et al., 2010). Many multinational companies have outsourced their logistics processes to third-party logistics providers and consider them their strategic partners.

Many research projects have been developed in the transportation and logistics industries that use available data that generated by road sensors, GPS devices and customers' websites (Ayed et al., 2015). Logistics providers manage a high volume of product flow and have access to a considerable volume of data. Any measurable criterion of product flow-such as origin, destination, size, weight, price, load content, etc.-can be a valuable method by which to use information for value creation (Mikavicaa et al., 2015). Improvements in GPS efficiency, applications of sensor networks, and developments in the Internet of Things have opened up new areas in logistics and supply chain automation (Ashton, 2009).

Optimizing service experiences such as delivery time, resource application, and geographical coverage are continuous challenges for logistics systems (Mikavicaa et al., 2015). Both delayed and early deliveries would be costly for logistics providers. This time difference between the planned delivery and the actual delivery is one of the key risk factors for logistics companies. Weather forecasts and vehicles' performance reliability data can be used to minimize the risk of inaccurate delivery times (Shang et al., 2017).

Big data logistics can be defined as modeling and analyzing logistics systems using big data sets which have been generated by GPS devices, cell phones, and the logistics companies' operations. Considering the current trend of big data applications in the logistics industry, it can be safely said that the logistics industry is in a transition phase from product-based services to information-based services (Mehmood \& Graham, 2015).

There are important business processes in the logistics industry such as forecasting, transportation, inventory management, and human resource planning and management that can be improved by using big data (Chen et al., 2014; Robak et al., 2014). Jin \& Kim (2018) combined big data analytics and business intelligence to minimize the analysis cost for the sorting and logistics processes of a courier firm. The other possible applications are forecasting delivery times, managing customer relationships, developing real-time scheduling, and managing supplier relationships.

Data mining applications for logistics management are threefold: 1- Data analysis to match the needs of both logistics process management and the customer; 2- Data analysis to manage the logistics process based on methodical decisions; and 3- A supporting role for logistics managers (lannone, 2012). Network technology developments can improve logistics processes by using information regarding real-time transactions. As a result of the increased adaptability of logistics information, logistics has been transformed into a dynamic data process (Xu, 2016). Niu et al. (2019) studied two competing air cargo carriers and showed how using big data analytics benefits a carrier by allowing them to receive updated demand signals. There are many quality papers in this field; some of these journal articles are summarized in Table 3.

Table 3. High-quality articles using big data in logistics processes (Citation count is as of March 2020).

\begin{tabular}{|c|c|c|c|c|c|}
\hline Author/Journal & Contribution & Study approach & $\begin{array}{l}\text { Case study (NA } \\
\text { stands for Not } \\
\text { Applicable) }\end{array}$ & Citation\# & $\begin{array}{c}\text { Future research topic(s) in } \\
\text { the article }\end{array}$ \\
\hline $\begin{array}{l}\text { Mehmood \& Graham } \\
\text { (2015)/Procedia } \\
\text { Computer Science }\end{array}$ & $\begin{array}{l}\text { lmproving } \\
\text { transportation system } \\
\text { efficiency by sharing } \\
\text { load and capacity }\end{array}$ & $\begin{array}{l}\text { Mathematical } \\
\text { modelling }\end{array}$ & $\begin{array}{l}\text { Healthcare transport } \\
\text { operations in the } \\
\text { United Kingdom, US, } \\
\text { France, and the Middle } \\
\text { East }\end{array}$ & 67 & $\begin{array}{l}\text {-Exploring load } \\
\text { optimization in fields } \\
\text { such as "bike sharing", } \\
\text { "waste management", } \\
\text { and "manufacturing plant } \\
\text { location / freight delivery" }\end{array}$ \\
\hline $\begin{array}{l}\text { Zhong et al. (2015)/ } \\
\text { International Journal of } \\
\text { Production Economics }\end{array}$ & $\begin{array}{l}\text { Using RFID logistics } \\
\text { big data to develop a } \\
\text { smart manufacturing } \\
\text { environment }\end{array}$ & $\begin{array}{l}\text { Spatio-temporal } \\
\text { sequential RFID } \\
\text { patterns / RFID- } \\
\text { Cuboid algorithm }\end{array}$ & $\begin{array}{l}\text { Unnamed collaborative } \\
\text { company with } 4 \\
\text { manufacturing shop } \\
\text { floors }\end{array}$ & 277 & $\begin{array}{l}\text {-Developing a mathematical } \\
\text { model to integrate } \\
\text { production planning, } \\
\text { scheduling, and material } \\
\text { delivery strategy } \\
\text {-Extending the evaluations } \\
\text { of the aforementioned } \\
\text { approach to big data }\end{array}$ \\
\hline $\begin{array}{l}\text { Kaur \& Singh } \\
\text { (2018)/Computers \& } \\
\text { Operations Research }\end{array}$ & $\begin{array}{l}\text { Developing a big } \\
\text { data analytics model } \\
\text { to make optimal } \\
\text { sustainable logistics } \\
\text { decisions }\end{array}$ & $\begin{array}{l}\text { Mixed integer } \\
\text { linear \& nonlinear } \\
\text { programming / } \\
\text { Heuristic method }\end{array}$ & $\begin{array}{l}\text { Unnamed } \\
\text { manufacturing } \\
\text { industries }\end{array}$ & 45 & $\begin{array}{l}\text {-Considering stochastic } \\
\text { parameters along with big } \\
\text { data } \\
\text {-Considering late deliveries } \\
\text { and shortages in a } \\
\text { mathematical model }\end{array}$ \\
\hline
\end{tabular}


Table 3. Continued...

\begin{tabular}{|c|c|c|c|c|c|}
\hline Author/Journal & Contribution & Study approach & $\begin{array}{l}\text { Case study (NA } \\
\text { stands for Not } \\
\text { Applicable) }\end{array}$ & Citation\# & $\begin{array}{c}\text { Future research topic(s) in } \\
\text { the article }\end{array}$ \\
\hline $\begin{array}{l}\text { Witkowski (2017)/ } \\
\text { Procedia Engineering }\end{array}$ & $\begin{array}{l}\text { Creating smart } \\
\text { solutions for logistics } \\
\text { in the global market }\end{array}$ & Analytical study & NA & 192 & NA \\
\hline $\begin{array}{l}\text { Hopkins \& Hawking } \\
\text { (2018)/The International } \\
\text { Journal of Logistics } \\
\text { Management }\end{array}$ & $\begin{array}{l}\text { Using big data } \\
\text { analytics and the } \\
\text { lnternet of Things to } \\
\text { increase driver safety, } \\
\text { reduce operating costs, } \\
\text { and improve vehicles' } \\
\text { environmental impact }\end{array}$ & Analytical framework & $\begin{array}{l}\text { Data from } 2012 \text { to } \\
2016 \text { from a company } \\
\text { in the logistics field }\end{array}$ & 32 & NA \\
\hline $\begin{array}{l}\text { Wu \& Lin (2018)/ } \\
\text { Telematics and } \\
\text { Informatics }\end{array}$ & $\begin{array}{l}\text { Generating logistical } \\
\text { strategies by using } \\
\text { unstructured big data }\end{array}$ & Analytical field study & $\begin{array}{l}\text { Open-access } \\
\text { logistic e-commerce } \\
\text { professional websites }\end{array}$ & 20 & $\begin{array}{l}\text {-lnvestigating various types } \\
\text { of unstructured data to } \\
\text { develop logistical strategies } \\
\text {-lmplementing studies on } \\
\text { structured e-commerce } \\
\text { logistics data }\end{array}$ \\
\hline
\end{tabular}

\section{Conclusions}

\subsection{Hurdles}

Despite of all the big data benefits for businesses, applying big data has not been accepted at the management level of many companies yet; this may be because the cost of using big data requires a high initial investment. Management support has a crucial role in the successful implementation of a big data analysis system. An initial cost-and-benefit assessment of big data in terms of how it will be utilized long-term is a very difficult task. It is not easy to determine applying big data analysis is beneficial for businesses that make fewer than a certain number of transactions every day. In some companies, such as Amazon, Walmart, Google, etc., traditional systems cannot be used to analyze the data because of how enormous the volume is. However, in some other companies, the $\mathrm{V}$ characteristics of big data are more questionable, and there is no rule of thumb to help tell the manager that the available data is suitable for establishing a big data analytics framework.

One of the problems with big data applications is knowing how, where, and by which means to collect useful data. Another issue has to do with inadvertently separating valuable information out of the available data. The analyst should know the information that he/she wants to exclude from the data; additionally, the available data should be able to answer the analyst's questions. Yet another problem regards finding the methods by which one can provide the most accurate answer while still using a reasonable amount of time and financial cost. There is an increasing demand for employees who are qualified to analyze big data as companies respond to the rapid pace of technology developments. It is also a challenge to create trust between data analysts and the managers. Most systems originally resist change, so it is vital to have the higher-level managers' support in order to use the results of data analysis to change a system.

A computers' Central Processing Unit (CPU) could be an obstacle for big data analysis because of the underdeveloped capability of traditional computers to store and effectively process a big data set. On the other hand, not all of the available raw data is complete and consistent; therefore, effective cleaning and integration methods are required to make the dataset ready for analysis.

The $5^{\text {th }}$ "V" added to the definition of big data refers to the value that can be obtained from a big data analysis. Unfortunately, whenever value comes in, hacking can start to crop up as well. Information security can be a hurdle to applying big data analysis in companies. A huge data volume increases the probability of having confidential and valuable information in the system, and this may increase data vulnerability and the chance of cybercriminals (Kshetri, 2014).

Another issue can be selecting the appropriate type of decision-making data for most of a system. More explicitly, not all of the available data in a system is used for making each and every decision. These decisions are based on the knowledge and experience of the data analyst that determine the part of a dataset that should be used. Moreover, it is an unfortunate fact that the available big data may not necessarily be created by the target population. For example, there is a huge volume of information on Twitter, but not everyone in a community will have Twitter accounts. Thus, there is a part of community which creates a lot of data, while the other part is not involved in creating any of the available information in a dataset. This fact continuously emphasizes statistical uncertainties such as biased statistics. 
Applying the results of a non-real-time data analysis can lead to a significant difference between the analysis for both the historical data and the real-time data; for example, the initial assumption of the forecasting analysis that "the future follows the past" would not be true. As an additional example, when the data shows the proficiency of a transportation path in terms of cost and time (many companies have access to this data), other companies may start to use this same path. By increasing the demand for the mentioned path, it may lose its attractiveness both in terms of cost and time.

Another old and common challenge is sharing data between the echelons of a supply chain, or even various departments of a plant. It is challenging to ensure that all the stakeholders who share data receive some benefits from this cooperation. Moreover, it is vital to have a supportive information technology department which provides both the hardware and software requirements for working with big data. Data analysts who can work with big data should be hired, or knowledgeable instructors should be easy to contact so that they can educate the big data analysts for the plant.

\subsection{Advantages}

Big data analytics can help companies better understand their business needs. Many companies plan their business growth model according to a demand boom, which may be the result of business growth in general. However, they should consider that a change in market growth may leave them with several empty warehouses and idle manufacturing plants. Big data enables these firms to predict the market direction and plan development strategies based on this analytical information.

Using big data enables companies to simulate a digital model of an entire manufacturing process. Collected data from the customers can be used to improve the marketing and sales processes. Clustering the customers into various groups, providing service according to the needs of each group, and using customers' data to target where/when to advertise these new products are the other applications of big data in marketing.

The importance of big data analytics in improving customer loyalty is not negligible. Most customers would be loyal to the company which provides them a high-quality service the first time. Companies can use big data analysis to predict customers' needs and satisfy those needs in order to make them loyal customers.

Optimizing activities which are out of the normal boundaries of the company-such as supplier selection or technological adjustments-require a high level of information-sharing between the stakeholders in a supply chain. Sharing information has always been an obstacle in supply chains, but big data technological developments can help simplify and speed up this process (Swaminathan, 2012).

From a logistical point of view, big data can be applied in order to forecast delivery times or optimize delivery routing by using traffic, weather, and drivers' information. Another possible application is to use the products' information in making inventory management and sales decisions (Waller \& Fawcett, 2013).

\subsection{Directions for future studies}

Both the literature and a review of companies' experience in the area of using big data analytics in manufacturing shows that the number of applied case studies are more than the number of theoretical publications. It is likely that researchers will develop more novel applications for big data in manufacturing systems, such as developing methods that can obtain high-quality solutions using less time and money.

Big data has been widely used for predictive studies in the literature, but there are not many prediction error measurement studies in big data. More precisely, beyond simply the quality of the input data, the accuracy of big data analysis is significantly affected by the quality of the model used to analyze the data. We still have a way to go regarding developing measures which can determine the accuracy of a big data analysis method.

The current studies regarding big data applications in supply chain management are mostly theoretical and conceptual, and there is a noticeable shortage of studies of analytical models. Moreover, the existing analytical models mostly study big data applications in modeling sustainability. Therefore, there is still a gap in the application of big data regarding optimizing operations (such as logistics and procurement) in a supply chain.

There are some study directions in big data that can significantly improve the performance of logistics systems: 1- Developing an efficient collaboration among all the decision makers, transporters, retailers, and door-to-door delivery service providers; and 2- Applying cloud-based services in smart transportation systems and integrating them in an online planning framework in order to provide a connection between vehicles, traffic managers, and the final customers. 
Finally, a good research topic to follow would be to find out if analyzing a sample of a big data set could give us the same quality results as the basic big data analytics. Design of experiment methods can be used for categorizing big data into different groups in order to save time regarding analysis.

\section{References}

Agrahri, H., Ahmed, F., Verma, V. K., \& Purohit, J. K. (2017). Benefits of implement big data driven supply chain management: an ISM based model. International Journal of Engineering Science, 75), 11426-11431.

Akter, S., \& Wamba, S. F. (2019). Big data and disaster management: a systematic review and agenda for future research. Annals of Operations Research, 283(1-2), 939-959. http://dx.doi.org/10.1007/s10479-017-2584-2.

Aloysius, J. A., Hoehle, H., Goodarzi, S., \& Venkatesh, V. (2018). Big data initiatives in retail environments: linking service process perceptions to shopping outcomes. Annals of Operations Research, 270(1-2), 25-51. http://dx.doi.org/10.1007/s10479-016-2276-3.

Andersson, J., \& Jonsson, P. (2018). Big data in spare parts supply chains. International Journal of Physical Distribution \& Logistics Management, 48(5), 524-544. http://dx.doi.org/10.1108/1JPDLM-01-2018-0025.

Arunachalam, D., Kumar, N., \& Kawalek, J. P. (2018). Understanding big data analytics capabilities in supply chain management: unravelling the issues, challenges and implications for practice. Transportation Research Part E, Logistics and Transportation Review, 114, 416-436. http://dx.doi.org/10.1016/j.tre.2017.04.001.

Ashton, K. (2009). That 'internet of things' thing. RFID Journal, 22(7), 97-114.

Ayed, A. B., Halima, M. B., \& Alimi, A. M. (2015). Big data analytics for logistics and transportation. In Proceedings of the 4th International Conference on Advanced Logistics and Transport (ICALT) (pp. 311-316). Piscataway: IEEE.

Badiezadeh, T., Saen, R. F., \& Samavati, T. (2018). Assessing sustainability of supply chains by double frontier network DEA: a big data approach. Computers \& Operations Research, 98, 284-290. http://dx.doi.org/10.1016/j.cor.2017.06.003.

Barbosa, M. W., Vicente, A. C., Ladeira, M. B., \& Oliveira, M. P. V. (2018). Managing supply chain resources with big data analytics: a systematic review. International Journal of Logistics Research and Applications, 21(3), 177-200. http://dx.doi.org/10.1080/13675 567.2017.1369501.

Barratt, M., \& Oke, A. (2007). Antecedents of supply chain visibility in retail supply chains: a resource-based theory perspective. Journal of Operations Management, 25(6), 1217-1233. http://dx.doi.org/10.1016/j.jom.2007.01.003.

Belhadi, A., Zkik, K., Cherrafi, A., \& Yusof, M. (2019). Understanding the capabilities of big data analytics for manufacturing process: insights from literature review and multiple case study. Computers \& Industrial Engineering, 137, 106099. http://dx.doi.org/10.1016/j. cie.2019.106099.

Benhenni, A. L. (2017). Pragmatic big data and smart manufacturing. In Proceedings of the 18th International Congress of Metrology. France: EDP Sciences. http://dx.doi.org/10.1051/metrology/201709002.

Biswas, S., \& Sen, J. (2016). A proposed framework of next generation supply chain management using big data analytics. In Proceedings of the National Conference on Emerging Trends in Business and Management: Issues and Challenges. Rourkela: National Institute of Technology Rourkela.

Boone, C. A., Skipper, J. B., \& Hazen, B. T. (2017). A framework for investigating the role of big data in service parts management. Journal of Cleaner Production, 153, 687-691. http://dx.doi.org/10.1016/j.jclepro.2016.09.201.

Boone, T., Ganeshan, R., Jain, A., \& Sanders, N. R. (2019). Forecasting sales in the supply chain: consumer analytics in the big data era. International Journal of Forecasting, 35(1), 170-180. http://dx.doi.org/10.1016/j.jforecast.2018.09.003.

Brandon-Jones, E., Squire, B., Autry, C. W., \& Petersen, K. J. (2014). A contingent resource-based perspective of supply chain resilience and robustness. The Journal of Supply Chain Management, 50(3), 55-73. http://dx.doi.org/10.1111/jscm.12050.

Briggs, E., Landry, T. D., \& Daugherty, P. J. (2010). Investigating the influence of velocity performance on satisfaction with third party logistics service. Industrial Marketing Management, 39(4), 640-649. http://dx.doi.org/10.1016/j.indmarman.2009.06.004.

Brinch, M. (2018). Understanding the value of big data in supply chain management and its business processes. International Journal of Operations \& Production Management, 38(7), 1589-1614. http://dx.doi.org/10.1108/1JOPM-05-2017-0268.

Brinch, M., Stentoft, J., Jensen, J. K., \& Rajkumar, C. (2018). Practitioners understanding of big data and its applications in supply chain management. International Journal of Logistics Management, 29(2), 555-574. http://dx.doi.org/10.1108/1JLM-05-2017-0115.

Bumblauskas, D., Gemmill, D., Igou, A., \& Anzengruber, J. (2017a). Smart Maintenance Decision Support Systems (SMDSS) based on corporate big data analytics. Expert Systems with Applications, 90, 303-317. http://dx.doi.org/10.1016/j.eswa.2017.08.025.

Bumblauskas, D., Nold, H., Bumblauskas, P., \& lgou, A. (2017b). Big data analytics: transforming data to action. Business Process Management Journal, 23(3), 703-720. http://dx.doi.org/10.1108/BPMJ-03-2016-0056.

Carillo, K. D. A. (2017). Let's stop trying to be "sexy": preparing managers for the (big) data-driven business era. Business Process Management Journal, 23(3), 598-622. http://dx.doi.org/10.1108/BPMJ-09-2016-0188.

Chaudhuri, A., Dukovska-Popovska, 1., Chan, H. K., Subramanian, N., Bai, R., \& Pawar, K. S. (2016). Development of a framework for big data analytics in cold chain logistics. In Proceedings of 21st International Symposium on Logistics (ISL 2016): Sustainable Transport and Supply Chain Innovation. Nottingham: Centre for Concurrent Enterprise, Nottingham University Business School.

Chen, D. Q., Preston, D. S., \& Swink, M. (2015). How the use of big data analytics affects value creation in supply chain management. Journal of Management Information Systems, 32(4), 4-39. http://dx.doi.org/10.1080/07421222.2015.1138364.

Chen, M., Mao, S., Zhang, Y., \& Leung, V. C. (2014). Big data: related technologies, challenges and future prospects. Cham: Springer International Publishing.

Cheng, Y., Kuang, Y., Shi, X., \& Dong, C. (2018). Sustainable investment in a supply chain in the big data era: an information updating approach. Sustainability, 10(2), 403. http://dx.doi.org/10.3390/su10020403. 
Choi, T.-M. (2018). Incorporating social media observations and bounded rationality into fashion quick response supply chains in the big data era. Transportation Research Part E, Logistics and Transportation Review, 114, 386-397. http://dx.doi.org/10.1016/j. tre.2016.11.006.

Choi, T.-M., Wallace, S. W., \& Wang, Y. (2018). Big data analytics in operations management. Production and Operations Management, 27(10), 1868-1883. http://dx.doi.org/10.1111/poms.12838.

Chopra, S., \& Meindl, P. (2007). Supply chain management. Strategy, planning \& operation. In C. Boersch \& R. Elschen (Eds.), Das summa summarum des management (pp. 265-275). Wiesbaden: Springer. http://dx.doi.org/10.1007/978-3-8349-9320-5_22.

Clarivate. (2020). CPCl: Clarivate analytics. Retrieved in 2020, March 25, from http://wokinfo.com/products_tools/multidisciplinary/ webofscience/cpci/?parentKey=555184,539593

Coble, K. H., Mishra, A. K., Ferrell, S., \& Griffin, T. (2018). Big data in agriculture: a challenge for the future. Applied Economic Perspectives and Policy, 40(1), 79-96. http://dx.doi.org/10.1093/aepp/ppx056.

Cochran, D. S., Kinard, D., \& Bi, Z. (2016). Manufacturing system design meets big data analytics for continuous improvement. Procedia CIRP, 50, 647-652. http://dx.doi.org/10.1016/j.procir.2016.05.004.

Costello, T., \& Prohaska, B. (2013). Trends and strategies. IT Professional, 15(1), 64. http://dx.doi.org/10.1109/MITP.2013.5.

Dai, Q., Zhong, R., Huang, G. Q., Qu, T., Zhang, T., \& Luo, T. Y. (2012). Radio frequency identification-enabled real-time manufacturing execution system: a case study in an automotive part manufacturer. International Journal of Computer Integrated Manufacturing, 25(1), 51-65. http://dx.doi.org/10.1080/0951192X.2011.562546.

Deleris, L. A., Elkins, D., \& Paté-Cornell, M. E. (2004). Analyzing losses from hazard exposure: a conservative probabilistic estimate using supply chain risk simulation. In Proceedings of the 2004 Winter Simulation Conference (pp. 1384-1391). Piscataway: IEEE. http://dx.doi.org/10.1109/WSC.2004.1371476.

Dubey, R., Gunasekaran, A., \& Childe, S. J. (2019). Big data analytics capability in supply chain agility. Management Decision, 57(8), 2092-2112. http://dx.doi.org/10.1108/MD-01-2018-0119.

Dubey, R., Gunasekaran, A., Childe, S. J., Luo, Z., Wamba, S. F., Roubaud, D., \& Foropon, C. (2018a). Examining the role of big data and predictive analytics on collaborative performance in context to sustainable consumption and production behaviour. Journal of Cleaner Production, 196, 1508-1521. http://dx.doi.org/10.1016/j.jclepro.2018.06.097.

Dubey, R., Luo, Z., Gunasekaran, A., Akter, S., Hazen, B. T., \& Douglas, M. A. (2018b). Big data and predictive analytics in humanitarian supply chains. International Journal of Logistics Management, 29(2), 485-512. http://dx.doi.org/10.1108/1JLM-02-2017-0039.

Dubey, R., Gunasekaran, A., Childe, S. J., Papadopoulos, T., Luo, Z., Wamba, S. F., \& Roubaud, D. (2019a). Can big data and predictive analytics improve social and environmental sustainability? Technological Forecasting and Social Change, 144, 534-545. http:// dx.doi.org/10.1016/j.techfore.2017.06.020.

Dubey, R., Gunasekaran, A., Childe, S. J., Roubaud, D., Fosso Wamba, S., Giannakis, M., \& Foropon, C. (2019b). Big data analytics and organizational culture as complements to swift trust and collaborative performance in the humanitarian supply chain. International Journal of Production Economics, 210, 120-136. http://dx.doi.org/10.1016/j.jpe.2019.01.023.

Dubey, R., Gunasekaran, A., Childe, S. J., Wamba, S. F., \& Papadopoulos, T. (2016). The impact of big data on world-class sustainable manufacturing. International Journal of Advanced Manufacturing Technology, 84(1-4), 631-645. http://dx.doi.org/10.1007/ s00170-015-7674-1.

Dutta, D., \& Bose, 1. (2015). Managing a big data project: the case of ramco cements limited. International Journal of Production Economics, 165, 293-306. http://dx.doi.org/10.1016/j.jpe.2014.12.032.

El-Kassar, A.-N., \& Singh, S. K. (2019). Green innovation and organizational performance: the influence of big data and the moderating role of management commitment and HR practices. Technological Forecasting and Social Change, 144, 483-498. http://dx.doi. org/10.1016/j.techfore.2017.12.016.

Engelseth, P., \& Wang, H. (2018). Big data and connectivity in long-linked supply chains. Journal of Business and lndustrial Marketing, 33(8), 1201-1208. http://dx.doi.org/10.1108/JBIM-07-2017-0168.

Feng, Q., \& Shanthikumar, J. G. (2018). How research in production and operations management may evolve in the era of big data. Production and Operations Management, 27(9), 1670-1684. http://dx.doi.org/10.1111/poms.12836.

Fisher, D., Deline, R., Czerwinski, M., \& Drucker, S. (2012). Interactions with big data analytics. Interaction, 19(3), 50-59. http://dx.doi. $\operatorname{org} / 10.1145 / 2168931.2168943$.

Gawankar, S. A., Gunasekaran, A., \& Kamble, S. (2020). A study on investments in the big data-driven supply chain, performance measures and organisational performance in Indian retail 4.0 context. International Journal of Production Research, 58(5), 15741593. http://dx.doi.org/10.1080/00207543.2019.1668070.

Giagnocavo, C., Bienvenido, F., Ming, L., Yurong, Z., Antonio Sanchez-Molina, J., \& Xinting, Y. (2017). Agricultural cooperatives and the role of organisational models in new intelligent traceability systems and big data analysis. International Journal of Agricultural and Biological Engineering, 10(5), 115-125. http://dx.doi.org/10.25165/j.jjabe.20171005.3089.

Giannakis, M., \& Louis, M. (2016). A multi-agent based system with big data processing for enhanced supply chain agility. Journal of Enterprise Information Management, 29(5), 706-727. http://dx.doi.org/10.1108/JEIM-06-2015-0050.

Gobble, M. M. (2013). Big data: the next big thing in innovation. Research Technology Management, 56(1), 64-67. http://dx.doi. org/10.5437/08956308X5601005.

Guha, S., \& Kumar, S. (2018). Emergence of big data research in operations management, information systems, and healthcare: Past contributions and future roadmap. Production and Operations Management, 279), 1724-1735. http://dx.doi.org/10.1111/poms.12833.

Gunasekaran, A., Papadopoulos, T., Dubey, R., Wamba, S. F., Childe, S. J., Hazen, B., \& Akter, S. (2017). Big data and predictive analytics for supply chain and organizational performance. Journal of Business Research, 70, 308-317. http://dx.doi.org/10.1016/j. jbusres.2016.08.004.

Gunasekaran, A., Yusuf, Y. Y., Adeleye, E. O., \& Papadopoulos, T. (2018). Agile manufacturing practices: the role of big data and business analytics with multiple case studies. International Journal of Production Research, 56(1-2), 385-397. http://dx.doi.org/1 0.1080/00207543.2017.1395488. 
Guo, L., Sharma, R., Yin, L., Lu, R., \& Rong, K. (2017). Automated competitor analysis using big data analytics. Business Process Management Journal, 23(3), 735-762. http://dx.doi.org/10.1108/BPMJ-05-2015-0065.

Gupta, S., Altay, N., \& Luo, Z. (2019a). Big data in humanitarian supply chain management: a review and further research directions. Annals of Operations Research, 283(1), 1153-1173. http://dx.doi.org/10.1007/s10479-017-2671-4.

Gupta, S., Chen, H., Hazen, B. T., Kaur, S., \& Santibañez Gonzalez, E. D. R. (2019b). Circular economy and big data analytics: a stakeholder perspective. Technological Forecasting and Social Change, 144, 466-474. http://dx.doi.org/10.1016/j.techfore.2018.06.030.

Gupta, S., Qian, X., Bhushan, B., \& Luo, Z. (2019c). Role of cloud ERP and big data on firm performance: a dynamic capability view theory perspective. Management Decision, 578), 1857-1882. http://dx.doi.org/10.1108/MD-06-2018-0633.

Gupta, S., Modgil, S., \& Gunasekaran, A. (2020). Big data in lean six sigma: a review and further research directions. International Journal of Production Research, 58(3), 947-969. http://dx.doi.org/10.1080/00207543.2019.1598599.

Hanumanthappa, M., \& Sarakutty, T. (2011). Predicting the future of car manufacturing industry using data mining techniques. International Journal of Information Technology, 1(1), 27-29.

Hazen, B. T., Boone, C. A., Ezell, J. D., \& Jones-Farmer, L. A. (2014). Data quality for data science, predictive analytics, and big data in supply chain management: an introduction to the problem and suggestions for research and applications. International Journal of Production Economics, 154, 72-80. http://dx.doi.org/10.1016/j.jpe.2014.04.018.

Hofmann, E. (2017). Big data and supply chain decisions: the impact of volume, variety and velocity properties on the bullwhip effect. International Journal of Production Research, 55(17), 5108-5126. http://dx.doi.org/10.1080/00207543.2015.1061222.

Hopkins, J., \& Hawking, P. (2018). Big data analytics and loT in logistics: a case study. International Journal of Logistics Management, 29(2), 575-591. http://dx.doi.org/10.1108/lJLM-05-2017-0109.

Hu, H., Wen, Y., Chua, T.-S., \& Li, X. (2014). Toward scalable systems for big data analytics: a technology tutorial. IEEE Access: Practical Innovations, Open Solutions, 2, 652-687. http://dx.doi.org/10.1109/ACCESS.2014.2332453.

Huang, L., Wu, C., \& Wang, B. (2019). Challenges, opportunities and paradigm of applying big data to production safety management: From a theoretical perspective. Journal of Cleaner Production, 231, 592-599. http://dx.doi.org/10.1016/j.jclepro.2019.05.245.

lannone, F. (2012). The private and social cost efficiency of port hinterland container distribution through a regional logistics system. Transportation Research Part A, Policy and Practice, 46(9), 1424-1448. http://dx.doi.org/10.1016/j.tra.2012.05.019.

ldc-Vesset, D., Woo, B., Morris, H., Villars, R., Little, G., Bozman, J. S., Borovick, L., Olofson, C. W., Feldman, S., \& Conway, S. (2012). Market analysis-worldwide big data technology and services 2012-2015 forecast. IDC Analyze the Future, 1, 1-34.

Irani, Z., Sharif, A. M., Lee, H., Aktas, E., Topaloğlu, Z., van’t Wout, T., \& Huda, S. (2018). Managing food security through food waste and loss: Small data to big data. Computers \& Operations Research, 98, 367-383. http://dx.doi.org/10.1016/j.cor.2017.10.007.

Ittmann, H. W. (2015). The impact of big data and business analytics on supply chain management. Journal of Transport and Supply Chain Management, 9(1), 1-9. http://dx.doi.org/10.4102/jtscm.v9i1.165.

Jagtap, S., \& Duong, L. N. K. (2019). Improving the new product development using big data: a case study of a food company. British Food Journal, 121(11), 2835-2848. http://dx.doi.org/10.1108/BFJ-02-2019-0097.

Jeble, S., Dubey, R., Childe, S. J., Papadopoulos, T., Roubaud, D., \& Prakash, A. (2018). Impact of big data and predictive analytics capability on supply chain sustainability. International Journal of Logistics Management, 29(2), 513-538. http://dx.doi.org/10.1108/ 1JLM-05-2017-0134.

Jha, M., Jha, S., \& O’Brien, L. (2016). Combining big data analytics with business process using reengineering. In Proceedings of the 2016 IEEE Tenth International Conference on Research Challenges in Information Science (RCIS) (pp. 1-6). Piscataway: IEEE. http:// dx.doi.org/10.1109/RCIS.2016.7549307.

Ji, G., \& Tan, K. (2017). A big data decision-making mechanism for food supply chain. In Proceedings of the 13th Global Congress on Manufacturing and Management (GCMM 2016) (Vol. 100). France: EDP Sciences.

Ji, S., \& Sun, Q. (2017). Low-carbon planning and design in B\&R logistics service: a case study of an e-commerce big data platform in China. Sustainability, 9(11), 2052. http://dx.doi.org/10.3390/su9112052.

Jin, D.-H., \& Kim, H.-J. (2018). Integrated understanding of big data, big data analysis, and business intelligence: a case study of logistics. Sustainability, 10(10), 3778. http://dx.doi.org/10.3390/su10103778.

Kache, F., \& Seuring, S. (2017). Challenges and opportunities of digital information at the intersection of big data analytics and supply chain management. International Journal of Operations \& Production Management, 37(1), 10-36. http://dx.doi.org/10.1108/ 1JOPM-02-2015-0078.

Kaur, H., \& Singh, S. P. (2018). Heuristic modeling for sustainable procurement and logistics in a supply chain using big data. Computers \& Operations Research, 98, 301-321. http://dx.doi.org/10.1016/j.cor.2017.05.008.

Kshetri, N. (2014). Big data' s impact on privacy, security and consumer welfare. Telecommunications Policy, 38(11), 1134-1145. http:// dx.doi.org/10.1016/j.telpol.2014.10.002.

Kumar, A., Shankar, R., Choudhary, A., \& Thakur, L. S. (2016). A big data MapReduce framework for fault diagnosis in cloud-based manufacturing. International Journal of Production Research, 54(23), 7060-7073. http://dx.doi.org/10.1080/00207543.2016.1153166.

Kusiak, A. (2017). Smart manufacturing must embrace big data. Nature, 544(7648), 23-25. http://dx.doi.org/10.1038/544023a. PMid:28383012.

Kynast, M., \& Marjanovic, O. (2016). Big Data in supply chain management-applications, challenges and benefits. In Proceedings of the 22nd Americas Conference on Information Systems. San Diego: AMCIS.

Lai, Y., Sun, H., \& Ren, J. (2018). Understanding the determinants of big data analytics (BDA) adoption in logistics and supply chain management. International Journal of Logistics Management, 29(2), 676-703. http://dx.doi.org/10.1108/1JLM-06-2017-0153.

Lamba, K., \& Singh, S. P. (2017). Big data in operations and supply chain management: Current trends and future perspectives. Production Planning and Control, 28(11-12), 877-890. http://dx.doi.org/10.1080/09537287.2017.1336787.

Lamba, K., \& Singh, S. P. (2019). Dynamic supplier selection and lot-sizing problem considering carbon emissions in a big data environment. Technological Forecasting and Social Change, 144, 573-584. http://dx.doi.org/10.1016/j.techfore.2018.03.020. 
Lamba, K., Singh, S. P., \& Mishra, N. (2019). Integrated decisions for supplier selection and lot-sizing considering different carbon emission regulations in big data environment. Computers \& Industrial Engineering, 128, 1052-1062. http://dx.doi.org/10.1016/j. cie.2018.04.028.

Laney, D. (2001a). Big 3D data management: Controlling data volume, velocity and variety. META Group Research Note, 6(71), 1.

Laney, D. (2001b). Application delivery strategies. Stamford: META Group.

Lau, R. Y. K., Zhang, W., \& Xu, W. (2018). Parallel aspect-oriented sentiment analysis for sales forecasting with big data. Production and Operations Management, 27(10), 1775-1794. http://dx.doi.org/10.1111/poms.12737.

Lee, C. K. H. (2017). A GA-based optimisation model for big data analytics supporting anticipatory shipping in Retail 4.0. International Journal of Production Research, 55(2), 593-605. http://dx.doi.org/10.1080/00207543.2016.1221162.

Lee, J., Lapira, E., Bagheri, B., \& Kao, H. (2013). Recent advances and trends in predictive manufacturing systems in big data environment. Manufacturing Letters, 1(1), 38-41. http://dx.doi.org/10.1016/j.mfglet.2013.09.005.

Li, B., Ch'ng, E., Chong, A. Y.-L., \& Bao, H. (2016). Predicting online e-marketplace sales performances: a big data approach. Computers \& Industrial Engineering, 101, 565-571. http://dx.doi.org/10.1016/j.cie.2016.08.009.

Li, L., Chi, T., Hao, T., \& Yu, T. (2018). Customer demand analysis of the electronic commerce supply chain using Big Data. Annals of Operations Research, 268(1-2), 113-128. http://dx.doi.org/10.1007/s10479-016-2342-x.

Li, S., Peng, G. C., \& Xing, F. (2019). Barriers of embedding big data solutions in smart factories: insights from SAP consultants. Industrial Management \& Data Systems, 119(5), 1147-1164. http://dx.doi.org/10.1108/lMDS-11-2018-0532.

Lin, C. (2016). Exploring big data capability: drivers and impact on supply chain performance. Toledo, $\mathrm{OH}$ : University of Toledo.

Liu, C., Li, H., Tang, Y., Lin, D., \& Liu, J. (2019). Next generation integrated smart manufacturing based on big data analytics, reinforced learning, and optimal routes planning methods. International Journal of Computer Integrated Manufacturing, 32(9), 820-831. http:// dx.doi.org/10.1080/0951192X.2019.1636412.

Liu, P. (2017). Pricing strategies of a three-stage supply chain: a new research in the big data era. Discrete Dynamics in Nature and Society, 2017, 2017. http://dx.doi.org/10.1155/2017/9024712.

Liu, P. (2019). Pricing policies and coordination of low-carbon supply chain considering targeted advertisement and carbon emission reduction costs in the big data environment. Journal of Cleaner Production, 210, 343-357. http://dx.doi.org/10.1016/j.jclepro.2018.10.328.

Liu, P., \& Yi, S. (2016). Investment decision-making and coordination of supply chain: a new research in the big data era. Discrete Dynamics in Nature and Society, 2016, 2016. http://dx.doi.org/10.1155/2016/2026715.

Liu, P., \& Yi, S. (2017). Pricing policies of green supply chain considering targeted advertising and product green degree in the big data environment. Journal of Cleaner Production, 164, 1614-1622. http://dx.doi.org/10.1016/j.jclepro.2017.07.049.

Liu, Y.-P., Guo, J.-F., \& Fan, Y. (2017). A big data study on emitting companies' performance in the first two phases of the European Union Emission Trading Scheme. Journal of Cleaner Production, 142, 1028-1043. http://dx.doi.org/10.1016/j.jclepro.2016.05.121.

Mandal, S. (2019). The influence of big data analytics management capabilities on supply chain preparedness, alertness and agility. Information Technology \& People, 32(2), 297-318. http://dx.doi.org/10.1108/lTP-11-2017-0386.

Mani, V., Delgado, C., Hazen, B. T., \& Patel, P. (2017). Mitigating supply chain risk via sustainability using big data analytics: evidence from the manufacturing supply chain. Sustainability, 9(4), 608. http://dx.doi.org/10.3390/su9040608.

Mashey, J. R. (1997). Big data... and the next wave of infrastress. In Proceedings of the Computer Science Division Seminar. Berkeley: University of California.

Mehmood, R., \& Graham, G. (2015). Big data logistics: a health-care transport capacity sharing model. Procedia Computer Science, 64, 1107-1114. http://dx.doi.org/10.1016/j.procs.2015.08.566.

Mikavicaa, B., Kostić-Ljubisavljevića, A., \& Radonjić, V. (2015). Big data: challenges and opportunities in logistics systems. In Proceedings of the 2nd Logistics International Conference (pp. 185-190). Belgrade, Serbia: LOGIC.

Militaru, G., Pollifroni, M., \& loanid, A. (2015). Big data in supply chain management: an exploratory study. Network Intelligence Studies, (6), 103-108.

Mishra, D., Gunasekaran, A., Papadopoulos, T., \& Childe, S. J. (2018). Big data and supply chain management: a review and bibliometric analysis. Annals of Operations Research, 270(1-2), 313-336. http://dx.doi.org/10.1007/s10479-016-2236-y.

Mishra, N., Singh, A., Rana, N. P., \& Dwivedi, Y. K. (2017). Interpretive structural modelling and fuzzy MICMAC approaches for customer centric beef supply chain: application of a big data technique. Production Planning and Control, 28(11-12), 945-963. http://dx.doi. org/10.1080/09537287.2017.1336789.

Moktadir, M. A., Ali, S. M., Paul, S. K., \& Shukla, N. (2019). Barriers to big data analytics in manufacturing supply chains: a case study from Bangladesh. Computers \& Industrial Engineering, 128, 1063-1075. http://dx.doi.org/10.1016/j.cie.2018.04.013.

Mourtzis, D., Vlachou, E., \& Milas, N. (2016). industrial big data as a result of loT adoption in manufacturing. Procedia Cirp, 55, 290295. http://dx.doi.org/10.1016/j.procir.2016.07.038.

Nedelcu, B. (2013). About big data and its challenges and benefits in manufacturing. Database Systems Journal, 4(3), 10-19.

Nguyen, T., Zhou, L., Spiegler, V., leromonachou, P., \& Lin, Y. (2018). Big data analytics in supply chain management: a state-of-the-art literature review. Computers \& Operations Research, 98, 254-264. http://dx.doi.org/10.1016/j.cor.2017.07.004.

Niebel, T., Rasel, F., \& Viete, S. (2019). BIG data-BIG gains? Understanding the link between big data analytics and innovation. Economics of Innovation and New Technology, 28(3), 296-316. http://dx.doi.org/10.1080/10438599.2018.1493075.

Niu, B., \& Zou, Z. (2017). Better demand signal, better decisions? Evaluation of big data in a licensed remanufacturing supply chain with environmental risk considerations. Risk Analysis, 37(8), 1550-1565. http://dx.doi.org/10.1111/risa.12796. PMid:28370119.

Niu, B., Dai, Z., \& Zhuo, X. (2019). Co-opetition effect of promised-delivery-time sensitive demand on air cargo carriers' big data investment and demand signal sharing decisions. Transportation Research Part E, Logistics and Transportation Review, 123, 29-44. http://dx.doi.org/10.1016/j.tre.2019.01.011.

O’Donovan, P., Leahy, K., Bruton, K., \& O'Sullivan, D. T. (2015). An industrial big data pipeline for data-driven analytics maintenance applications in large-scale smart manufacturing facilities. Journal of Big Data, 2(1), 25. http://dx.doi.org/10.1186/s40537-015-0034-z. 
Oncioiu, l., Bunget, O. C., Türkeș, M. C., Căpușneanu, S., Topor, D. 1., Tamaș, A. S., Rakoș, l.-S., \& Hint, M. (2019). The impact of big data analytics on company performance in supply chain management. Sustainability, 11(18), 4864. http://dx.doi.org/10.3390/su11184864.

Opresnik, D., \& Taisch, M. (2015). The value of big data in servitization. International Journal of Production Economics, 165, $174-184$. http://dx.doi.org/10.1016/j.jpe.2014.12.036.

Papadopoulos, T., Gunasekaran, A., Dubey, R., Altay, N., Childe, S. J., \& Fosso-Wamba, S. (2017). The role of big data in explaining disaster resilience in supply chains for sustainability. Journal of Cleaner Production, 142, 1108-1118. http://dx.doi.org/10.1016/j. jclepro.2016.03.059.

Popovič, A., Hackney, R., Tassabehji, R., \& Castelli, M. (2018). The impact of big data analytics on firms' high value business performance. Information Systems Frontiers, 20(2), 209-222. http://dx.doi.org/10.1007/s10796-016-9720-4.

Prasad, S., Zakaria, R., \& Altay, N. (2018). Big data in humanitarian supply chain networks: a resource dependence perspective. Annals of Operations Research, 270(1-2), 383-413. http://dx.doi.org/10.1007/s10479-016-2280-7.

Raut, R. D., Mangla, S. K., Narwane, V. S., Gardas, B. B., Priyadarshinee, P., \& Narkhede, B. E. (2019). Linking big data analytics and operational sustainability practices for sustainable business management. Journal of Cleaner Production, 224, 10-24. http://dx.doi. org/10.1016/j.jclepro.2019.03.181.

Rehman, M. H., Chang, V., Batool, A., \& Wah, T. Y. (2016). Big data reduction framework for value creation in sustainable enterprises. International Journal of Information Management, 36(6), 917-928. http://dx.doi.org/10.1016/j.ijinfomgt.2016.05.013.

Reinsel, D., Gantz, J., \& Rydning, J. (2018). The digitization of the world from edge to core (IDC White Paper). Framingham, MA: IDC.

Ren, S., Zhang, Y., Liu, Y., Sakao, T., Huisingh, D., \& Almeida, C. M. (2019). A comprehensive review of big data analytics throughout product lifecycle to support sustainable smart manufacturing: a framework, challenges and future research directions. Journal of Cleaner Production, 210, 1343-1365. http://dx.doi.org/10.1016/j.jclepro.2018.11.025.

Rialti, R., Marzi, G., Ciappei, C., \& Busso, D. (2019). Big data and dynamic capabilities: a bibliometric analysis and systematic literature review. Management Decision, 578), 2052-2068. http://dx.doi.org/10.1108/MD-07-2018-0821.

Richey Junior, R. G., Morgan, T. R., Lindsey-Hall, K., \& Adams, F. G. (2016). A global exploration of big data in the supply chain. International Journal of Physical Distribution \& Logistics Management, 46(8), 710-739. http://dx.doi.org/10.1108/IJPDLM-05-2016-0134

Robak, S., Franczyk, B., \& Robak, M. (2014). Research problems associated with big data utilization in logistics and supply chains design and management. Annals of Computer Science and Information Systems, 3, 245-249. http://dx.doi.org/10.15439/2014F472.

Roßmann, B., Canzaniello, A., von der Gracht, H., \& Hartmann, E. (2018). The future and social impact of big data analytics in supply chain management: results from a Delphi study. Technological Forecasting and Social Change, 130, 135-149. http://dx.doi. org/10.1016/j.techfore.2017.10.005.

Sagaert, Y. R., Aghezzaf, E.-H., Kourentzes, N., \& Desmet, B. (2018). Temporal big data for tactical sales forecasting in the tire industry. Interfaces, 48(2), 121-129. http://dx.doi.org/10.1287/inte.2017.0901.

Sanders, N. R. (2014). Big data driven supply chain management: a framework for implementing analytics and turning information into intelligence. New Jersey: Pearson Education.

Sanders, N. R. (2016). How to use big data to drive your supply chain. California Management Review, 58(3), 26-48. http://dx.doi. org/10.1525/cmr.2016.58.3.26.

Santos, M. Y., Oliveira e Sá, J., Andrade, C., Vale Lima, F., Costa, E., Costa, C., Martinho, B., \& Galvão, J. (2017). A big data system supporting bosch braga industry 4.0 strategy. International Journal of Information Management, 376), 750-760. http://dx.doi. org/10.1016/j.jinfomgt.2017.07.012.

Schoenherr, T., \& Speier-Pero, C. (2015). Data science, predictive analytics, and big data in supply chain management: current state and future potential. Journal of Business Logistics, 36(1), 120-132. http://dx.doi.org/10.1111/jbl.12082.

Schroeck, M., Shockley, R., Smart, J., Romero-Morales, D., \& Tufano, P. (2012). Analytics: the real-world use of big data. IBM Global Business Services, 12, 1-20.

Schwab, K., Marcus, A., Oyola, J. O., Hoffman, W., \& Luzi, M. (2011). Personal data: the emergence of a new asset class: an initiative of the World Economic Forum. Geneva: World Economic Forum.

Seles, B. M. R. P., Sousa Jabbour, A. B. L., Jabbour, C. J. C., Camargo Fiorini, P., Mohd-Yusoff, Y., \& Thomé, A. M. T. (2018). Business opportunities and challenges as the two sides of the climate change: Corporate responses and potential implications for big data management towards a low carbon society. Journal of Cleaner Production, 189, 763-774. http://dx.doi.org/10.1016/j.jclepro.2018.04.113.

Shang, Y., Dunson, D., \& Song, J.-S. (2017). Exploiting big data in logistics risk assessment via bayesian nonparametrics. Operations Research, 65(6), 1574-1588. http://dx.doi.org/10.1287/opre.2017.1612.

Shen, B., Choi, T.-M., \& Chan, H.-L. (2019). Selling green first or not? A Bayesian analysis with service levels and environmental impact considerations in the big data era. Technological Forecasting and Social Change, 144, 412-420. http://dx.doi.org/10.1016/j. techfore.2017.09.003.

Shukla, M., \& Mattar, L. (2019). Next generation smart sustainable auditing systems using big data analytics: understanding the interaction of critical barriers. Computers \& Industrial Engineering, 128, 1015-1026. http://dx.doi.org/10.1016/j.cie.2018.04.055.

Shukla, M., \& Tiwari, M. K. (2017). Big-data analytics framework for incorporating smallholders in sustainable palm oil production. Production Planning and Control, 28(16), 1365-1377. http://dx.doi.org/10.1080/09537287.2017.1375145.

Singh, S. K., \& El-Kassar, A.-N. (2019). Role of big data analytics in developing sustainable capabilities. Journal of Cleaner Production, 213, 1264-1273. http://dx.doi.org/10.1016/j.jclepro.2018.12.199.

Sonra. (2015, June 15). Data warehousing in the age of big data: RDBMS scalability, exploding data volumes and license costs. Retrieved in 2020, March 25, from https://sonra.io/2015/06/15/data-warehousing-in-the-age-of-big-data-rdbms-scalability-exploding-datavolumes-and-license-costs/

StatSlice. (2013). Hadoop business case: a cost effective queryable data archive/storage platform. Retrieved in 2020, March 25, from http://www.statslice.com/hadoop-business-case-a-cost-effective-queryable-data-archivestorage-platform

Swafford, P. M., Ghosh, S., \& Murthy, N. (2008). Achieving supply chain agility through IT integration and flexibility. International Journal of Production Economics, 116(2), 288-297. http://dx.doi.org/10.1016/j.jpe.2008.09.002. 
Swaminathan, S. (2012). The effects of big data on the logistics industry. Redwood City: Profit Oracle.

Tan, K. H., Zhan, Y., Ji, G., Ye, F., \& Chang, C. (2015). Harvesting big data to enhance supply chain innovation capabilities: an analytic infrastructure based on deduction graph. International Journal of Production Economics, 165, 223-233. http://dx.doi.org/10.1016/j. ijpe.2014.12.034.

Tao, F., Cheng, J., Qi, Q., Zhang, M., Zhang, H., \& Sui, F. (2018). Digital twin-driven product design, manufacturing and service with big data. International Journal of Advanced Manufacturing Technology, 94(9-12), 3563-3576. http://dx.doi.org/10.1007/s00170017-0233-1.

Terziovski, M. (2010). Innovation practice and its performance implications in small and medium enterprises (SMEs) in the manufacturing sector: a resource-based view. Strategic Management Journal, 31(8), 892-902. http://dx.doi.org/10.1002/smj.841.

Tsao, Y.-C. (2017). Managing default risk under trade credit: Who should implement Big-Data analytics in supply chains? Transportation Research Part E, Logistics and Transportation Review, 106, 276-293. http://dx.doi.org/10.1016/j.tre.2017.08.013.

Van Asselt, E. D., van der Fels-Klerx, H. J., Marvin, H. J. P., Van Bokhorst-van de Veen, H., \& Groot, M. N. (2017). Overview of food safety hazards in the European dairy supply chain. Comprehensive Reviews in Food Science and Food Safety, 16(1), 59-75. http:// dx.doi.org/10.1111/1541-4337.12245.

Van der Aalst, W. M. (2012). A decade of business process management conferences: personal reflections on a developing discipline. In Proceedings of the International Conference on Business Process Management (pp. 1-16). Berlin: Springer. http://dx.doi. org/10.1007/978-3-642-32885-5_1.

Vera-Baquero, A., Colomo Palacios, R., Stantchev, V., \& Molloy, O. (2015). Leveraging big-data for business process analytics. The Learning Organization, 22(4), 215-228. http://dx.doi.org/10.1108/TL0-05-2014-0023.

Waller, M. A., \& Fawcett, S. E. (2013). Data science, predictive analytics, and big data: a revolution that will transform supply chain design and management. Journal of Business Logistics, 34(2), 77-84. http://dx.doi.org/10.1111/jbl.12010.

Wamba, S. F., Akter, S., Edwards, A., Chopin, G., \& Gnanzou, D. (2015). How 'big data'can make big impact: Findings from a systematic review and a longitudinal case study. International Journal of Production Economics, 165, 234-246. http://dx.doi.org/10.1016/j. ijpe.2014.12.031.

Wang, G., Gunasekaran, A., Ngai, E. W., \& Papadopoulos, T. (2016). Big data analytics in logistics and supply chain management: certain investigations for research and applications. International Journal of Production Economics, 176, 98-110. http://dx.doi. org/10.1016/j.jpe.2016.03.014.

Weerakkody, V., Kapoor, K., Balta, M. E., Irani, Z., \& Dwivedi, Y. K. (2017). Factors influencing user acceptance of public sector big open data. Production Planning and Control, 28(11-12), 891-905. http://dx.doi.org/10.1080/09537287.2017.1336802.

Weng, W.-H., \& Weng, W.-T. (2013). Forecast of development trends in big data industry. In Proceedings of the Institute of Industrial Engineers Asian Conference 2013 (pp. 1487-1494). Singapore: Springer. http://dx.doi.org/10.1007/978-981-4451-98-7_174.

Witkowski, K. (2017). Internet of things, big data, industry 4.0-: nnovative solutions in logistics and supply chains management. Procedia Engineering, 182, 763-769. http://dx.doi.org/10.1016/j.proeng.2017.03.197.

Wolfert, S., Ge, L., Verdouw, C., \& Bogaardt, M.-J. (2017). Big data in smart farming: a review. Agricultural Systems, 153, 69-80. http:// dx.doi.org/10.1016/j.agsy.2017.01.023.

Wu, K.-J., Liao, C.-J., Tseng, M.-L., Lim, M. K., Hu, J., \& Tan, K. (2017). Toward sustainability: using big data to explore the decisive attributes of supply chain risks and uncertainties. Journal of Cleaner Production, 142, 663-676. http://dx.doi.org/10.1016/j. jclepro.2016.04.040.

Wu, P.-J., \& Lin, K.-C. (2018). Unstructured big data analytics for retrieving e-commerce logistics knowledge. Telematics and Informatics, 35(1), 237-244. http://dx.doi.org/10.1016/j.tele.2017.11.004.

Xu, F., Li, Y., \& Feng, L. (2019). The influence of big data system for used product management on manufacturing: remanufacturing operations. Journal of Cleaner Production, 209, 782-794. http://dx.doi.org/10.1016/j.jclepro.2018.10.240.

$\mathrm{Xu}$, L. (2016). Construction mode of efficient logistics system under the big data environment. Advanced Science and Technology Letters, 138, 150-155. http://dx.doi.org/10.14257/astl.2016.138.31.

Yadegaridehkordi, E., Hourmand, M., Nilashi, M., Shuib, L., Ahani, A., \& lbrahim, O. (2018). Influence of big data adoption on manufacturing companies' performance: an integrated DEMATEL-ANFIS approach. Technological Forecasting and Social Change, 137, 199-210. http://dx.doi.org/10.1016/j.techfore.2018.07.043.

Yu, L., Zhao, Y., Tang, L., \& Yang, Z. (2019). Online big data-driven oil consumption forecasting with Google trends. International Journal of Forecasting, 35(1), 213-223. http://dx.doi.org/10.1016/j.ijforecast.2017.11.005.

Zaki, M., Theodoulidis, B., Shapira, P., Neely, A., \& Tepel, M. F. (2019). Redistributed manufacturing and the impact of big data: a consumer goods perspective. Production Planning and Control, 30(7), 568-581. http://dx.doi.org/10.1080/09537287.2018.1540068.

Zhan, Y., Tan, K. H., Li, Y., \& Tse, Y. K. (2018). Unlocking the power of big data in new product development. Annals of Operations Research, 270(1-2), 577-595. http://dx.doi.org/10.1007/s10479-016-2379-x.

Zhang, Y., Ren, S., Liu, Y., \& Si, S. (2017). A big data analytics architecture for cleaner manufacturing and maintenance processes of complex products. Journal of Cleaner Production, 142, 626-641. http://dx.doi.org/10.1016/j.jclepro.2016.07.123.

Zhao, R., Liu, Y., Zhang, N., \& Huang, T. (2017). An optimization model for green supply chain management by using a big data analytic approach. Journal of Cleaner Production, 142, 1085-1097. http://dx.doi.org/10.1016/j.jclepro.2016.03.006.

Zhong, R. Y., Huang, G. Q., Lan, S., Dai, Q. Y., Chen, X., \& Zhang, T. (2015). A big data approach for logistics trajectory discovery from RFID-enabled production data. International Journal of Production Economics, 165, 260-272. http://dx.doi.org/10.1016/j. ijpe.2015.02.014.

Zhong, R. Y., Xu, C., Chen, C., \& Huang, G. Q. (2017). Big data analytics for physical internet-based intelligent manufacturing shop floors. International Journal of Production Research, 55(9), 2610-2621. http://dx.doi.org/10.1080/00207543.2015.1086037. 